OPEN ACCESS

Edited by:

Sara Hughes,

University of Michigan, United States

Reviewed by:

Erik Porse,

California State University,

United States

Prakriti Shukla,

University of Michigan, United States

*Correspondence:

Tahmina Yasmin

sumi0101@gmail.com

Specialty section: This article was submitted to Water and Built Environment, a section of the journal

Frontiers in Water

Received: 10 August 2021

Accepted: 25 January 2022

Published: 28 February 2022

Citation:

Yasmin T, Farrelly MA, Rogers BC, Krause S and Lynch I (2022) Hybrid and Multi-Level Adaptive Governance for Sustainable Urban Transformations in the Global South: A Secondary City

Case Study. Front. Water 4:756273.

doi: 10.3389/frwa.2022.756273

\section{Hybrid and Multi-Level Adaptive Governance for Sustainable Urban Transformations in the Global South: A Secondary City Case Study}

\author{
Tahmina Yasmin ${ }^{1,2 \star}$, Megan A. Farrelly ${ }^{3}$, Briony C. Rogers ${ }^{3}$, Stefan Krause ${ }^{1,2}$ and \\ Iseult Lynch ${ }^{1,2}$ \\ ${ }^{1}$ School of Geography, Earth and Environmental Sciences, The Institute for Global Innovation, University of Birmingham, \\ Birmingham, United Kingdom, ${ }^{2}$ School of Geography, Earth and Environmental Sciences, College of Life and Environmental \\ Sciences, University of Birmingham, Birmingham, United Kingdom, ${ }^{3}$ School of Social Sciences, Monash University, \\ Melbourne, VIC, Australia
}

The water governance crisis has critical implications for the transformation of cities through establishment of sustainable water management practices. Adaptive governance approaches, with their potential to address global water governance challenges, are emerging in the context of the global South (GS). A key feature of adaptive governance is its enabling context, or hybridized governance approach which bridges organizational and network activities across multiple implementation scales. Transforming urban water management toward sustainable water governance practices requires flexibility and agility, and a willingness to enable new ideas, features often associated with smaller and newer cities (secondary cities) which are less constrained than the major cities. However, unpacking their potentiality and the scope of such secondary cities to lead the way in transitioning to sustainable water governance remains under-researched. To address this gap, a qualitative study in a representative GS secondary city (Mymensingh in Bangladesh) was undertaken to investigate whether national and local strategies directed toward improving governance and management capacity of the local municipality are yielding sustainable transformations. We identified a significant shift within the governance regime that influences existing power dynamics and decision-making for the delivery of urban water services. Within the traditional state-led governance structure, a hybridized governance is emerging that builds both institutional and actor capacity. However, these hybridized governance activities are strongly dependent on (international) donor investment and guidance, therefore the presence or absence of donor support will likely determine the impact of these activities in the future.

Keywords: adaptive governance, global south, urban water management, secondary city, Bangladesh, sustainable transformation 


\section{INTRODUCTION}

Rethinking and reforming traditional water governance approaches in cities involves establishing integrated and sustainable water management practices (OECD, 2011, 2015). This is most pertinent to cities in the Global South (GS) where the implementation of integrated water resource management (IWRM) has yet to be achieved (Agyenim and Gupta, 2012; Yasmin et al., 2018). One reason for this shortcoming lies in the implementation framework which is rooted within traditional command and control governance regime attributes despite its emphasis on integration and adaptive management principles (Biswas and Tortajada, 2010; Halbe et al., 2013; OECD, 2015; UNDESA, 2015). Integrated and adaptive management principles require development of institutional and actor capacity to deliver strategies that can address the specific local water governance challenges, and furthermore, can transform the overarching water infrastructure into an adaptive and sustainable system (Biswas and Tortajada, 2010; Koop and van Leeuwen, 2015). Water governance challenges are further exaggerated in GS cities due to the added pressure arising from the continuous expansion of urban agglomerations due to fast population growth (Biswas and Tortajada, 2010). While unpacking these water governance challenges and the relevant capacity contexts is attracting the attention of scientists and policymakers, the focus is largely on major capital infrastructure and big cities, leaving secondary cities (medium and small towns with a population starting from 100,000 to several million) under-researched (Shah, 2013; Yasmin et al., 2018). Yet, these secondary cities are believed to present an important leverage point in urban system transformation, for these cities are yet to be extensively developed i.e., they are less path dependent (when present decisions are dependent on past decisions or experiences both good or bad) from an infrastructure viewpoint (e.g., from previous investments in wastewater treatment facilities etc.) and are thus more open to adoption of newer technologies and distributed systems (UN-Habitat, 2006; Makropoulos and Butler, 2010; de Noronha and Vaz, 2015; Tutusaus et al., 2018).

Recent efforts by both national and international donor organizations, like the Asian Development Bank (ADB) and the World Bank (WB), in secondary cities of GS countries are directed toward improving city governance approaches. However, the reality of these secondary cities is that they seriously lack the range of capacities (professional/practitioners/community) required to deliver basic urban services to their dwellers (Gupta, 2012; Zermoglio et al., 2020). Suspected reasons for this are the absence of dedicated water utilities and limited physical, human, and financial resources and an absence of governance capacity (Bunnell and Maringanti, 2010; Jaglin and Bousquet, 2011; Gupta, 2012; Shah, 2013; Tutusaus et al., 2018). Thus, it is necessary to establish whether newer donor-directed strategies and efforts in developing GS secondary cities are improving the capacity that is needed to build a governance system capable of urban transformation.
As a means to improve capacity to address governance challenges and guide transformation pathways, a combination and integration of adaptive governance and sustainable transition have been advocated (Folke et al., 2005; Pahl-Wostl, 2007; Yasmin et al., 2019). In particular, the adaptive governance framing has been widely used to influence policy and strategic planning (Folke et al., 2005; Pahl-Wostl, 2007; Biswas and Tortajada, 2010). Adaptive governance (AG) framing deals with complex socioecological systems and emphasizes improving coordination and co-management strategies to ensure sustainable resource management (Dietz et al., 2003; Folke et al., 2005; Yasmin et al., 2019). AG defines the critical attributes (for details please see Yasmin et al., 2019, p. 47) required for the transformation toward sustainability. A particular feature of AG is that it recognizes the multi-layered levels of governance structures and connects formal and informal institutional processes to promote innovation and transfer of learning. The AG framework thus offers scope for developing networks of diverse actors and supports wide stakeholder participation and collective efforts, that together enable transition toward sustainability and enhanced resilience. However, operationalisation of the AG approach remains vague and lacks critical empirical evidence, in particular in a GS context (Yasmin et al., 2019).

To date, urban water governance approaches have offered insights regarding enabling platforms and adaptive attributes that can guide sustainability transition pathways (see e.g., Brown et al., 2009; Wong and Brown, 2009; Rijke et al., 2013) and have identified important adaptive attributes for delivering sustainable resource management explicitly in GS contexts (see e.g., Clark and Semmahasak, 2013; Larson et al., 2013; Ahammad et al., 2014; Butler et al., 2014; Regmi et al., 2016; Azhoni et al., 2017). Nevertheless, little exploration has been directed toward understanding how these adaptive attributes can guide the transformation of cities, and in particular of secondary cities. In an attempt to understand the enabling context (i.e., the governance structures and processes that can offer new innovation or approaches to establish sustainable initiatives) and necessary adaptive attributes to support cities' governance transformation, Yasmin et al. (2019) developed the adaptive capacity and attributes (ACA) framework (re-drawn in Figure 1A), which revealed the critical enablers for supporting change and provided a list of the key adaptive attributes in governance structure, processes and feedback (presented herein as Figure 1B). These AG attributes are interconnected and interdependent across the critical dimensions including actors, institutions and scale (Yasmin et al., 2019). These key adaptive attributes include involvement of multiscale and polycentric institutions and bridging organizations, use of participatory and network approaches, and a clear focus on leadership and capacity development, which collectively nurture the steps (pathways) necessary to deliver adaptive capacity and further advancement toward sustainable urban transformations. Within such critical framing, scholars further suggested exploring these enabling contexts within contemporary practices in secondary cities could provide evidence for the importance of adaptive attributes that 
A

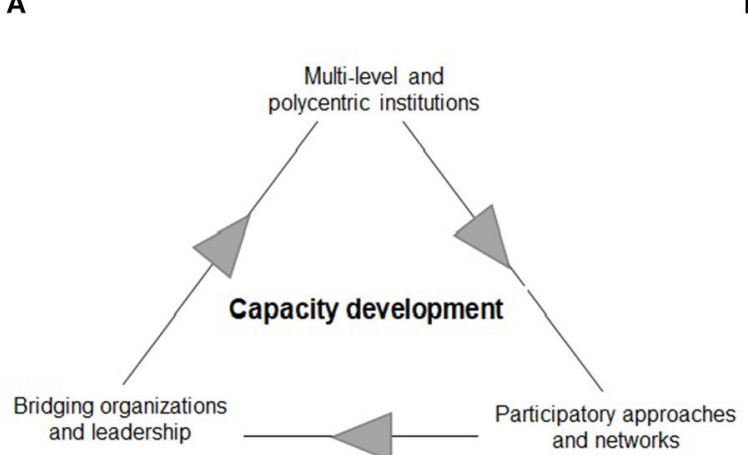

B



c

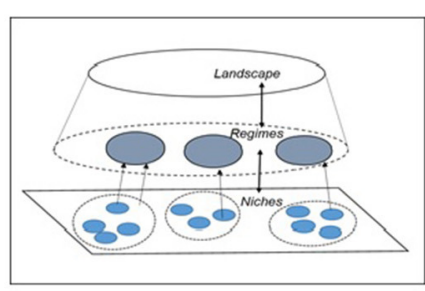

FIGURE 1 | Adaptive capacity attribute framework: (A) Enablers for change, (B) key adaptive governance attributes emerging from the global South context (adapted from Yasmin et al., 2019) (C) multi-level perspective (MLP) proposed by Rip and Kemp (1998), Rotmans et al. (2001), and Berkhout et al. (2010).

can lead to more sustainable urban water management practices. However, such exploration is scarce in academic literature to date.

The aim of this article is two-fold, first, to identify whether the adaptive attributes captured in the ACA framework are present in a secondary city's water management approach (using as a case study Mymensingh city, Bangladesh due to its recent implementation of innovative projects), and secondly, to explore whether those adaptive attributes are capable of guiding contemporary practices toward delivering sustainable urban water management outcomes and guiding cities transformation. Bangladesh (Mymensingh city) has been selected as the case example due to the fact that it is currently undergoing significant changes within the realm of its water resource management planning and strategies (Yasmin et al., 2018) driven by a need to overcome city-scale water pollution and climate-induced vulnerability (World Bank., 2017). Bangladesh incorporated IWRM into national water policy in 1999 and has been focusing on improving city-scale water management systems. Bangladesh has achieved significant success targeting the United Nations (UN) Millennium Development Goals, in particular in the public health sector, and is also ahead of target toward implementing its planned responses to achieve the UN Sustainable development Goals (SDGs) (Yasmin et al., 2018). The broader aim of the current government was to become a middle-income country by 2020 (delayed due to the COVID pandemic). To achieve this, a range of innovative strategies are currently being implemented at different scales including in secondary cities. As part of the decentralization scheme for addressing challenges in IWRM implementation, secondary cities' development received attention, in particular aiming to improve the governance capacity of lower administrative units (municipalities). Nevertheless, there has been limited research to explore whether these innovative and multi-scale strategies are useful for improving governance capacity in secondary cities, and whether this increased governance capacity results in measurable progress toward urban water development and sustainability.

To address this knowledge gap, this research utilizes the ACA framework and the multi-level perspectives (MLP) theory from sustainable transition which consists of three nested hierarchical scales, where "niche" represents innovations or new ideas within protected space, "regime" represents a more stable scale where established rules, regulations and institutions guide decision-making, and "landscape" represents broader sociopolitical and environmental change, as shown in Figure 1C) to analyse contemporary multi-scale strategies and initiatives for developing an urban water management system in the secondary city of Mymensingh in Bangladesh.

\section{RESEARCH METHODOLOGIES}

Similar to the approach undertaken in Yasmin et al. (2018), this article seeks to examine the historical and contemporary development of urban water systems in an emerging city within Bangladesh. This study investigates Mymensingh city case presented in Figure 2 to determine whether there is greater adaptive capacity within the system given the nascent urban water system. A single case study approach was adopted for exploring the multi-level context of historical and contemporary urban water management strategies, actions and activities in Mymensingh Pourashava. 
Population: 407798 (BBS, 2010)

Population density: $5000 / \mathrm{sq}$. KM

Monsoon temperature: $15 \sim 20^{\circ} \mathrm{C}$

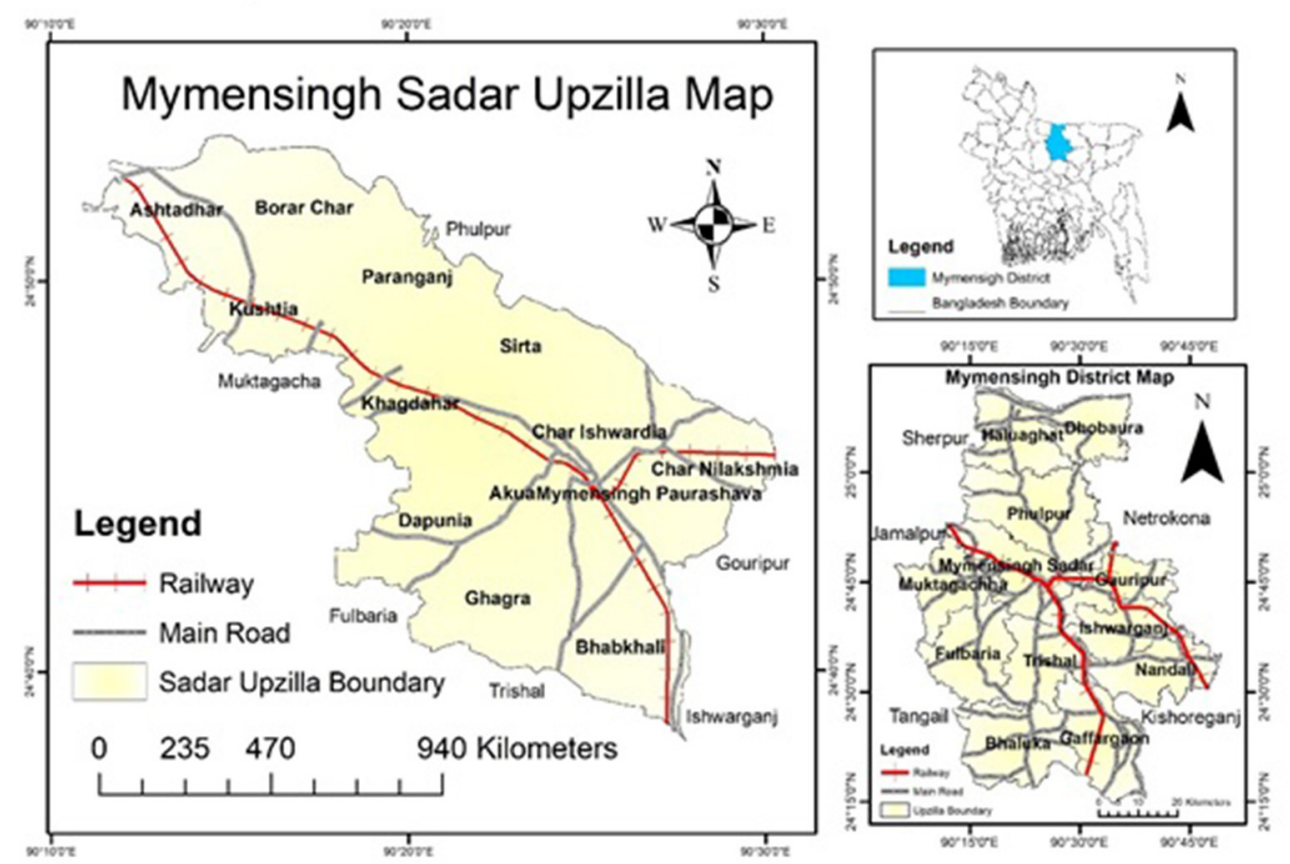

FIGURE 2 | Mymensingh District and Sadar Upzilla map.

\section{Geographical Context}

Pourushava-the local term for a municipality-is the formal public institution responsible for conducting city-building activities within Mymensingh, including water management (i.e., generating tax, solid waste management, cleaning and maintenance of development works such as roads and streetlights). Mymensingh Pourashava under the district of Mymensingh (Figure 2) was established in April 1869 and as of 2017 consisted of twenty-one wards (Pourashava report, 1972) and ninety-five slum settlements scattered across the city. Based on revenue (i.e., household tax, services tax, and/or fees) collected over the 3 years to 2017, Pourashavas in Bangladesh are categorized as "A," "B," or "C", where the "A" group, which the Mymensingh Pourashava falls under, have annual revenue more than or equal to BDT 6 million, while those in B generate BDT 2.5 million and C BDT 1 million (Urban Management unit, LGED: http://www.lged.gov.bd/UnitAbout.aspx?UnitID=10).

\section{Data Collection and Analysis}

Primary and secondary data collection included: (i) collating and analyzing newspaper articles (1878-2016) from newspaper archives available in university library databases: "NewsbankAustralia and the world," and (ii) reviewing the Pourashava's annual reports and water supply datasheets (source: collected from Mymensingh Pourashava). Further data collection involved mapping and examining contemporary water management approaches by identifying existing water supply and sanitation systems, and a detailed examination of two key urban water management projects currently implementing by Mymensingh Pourashava. The two urban water management projects [1. Second Urban Governance and Infrastructure Improvement Sector Project (UGIIP-II) and 2. The Mymensingh Strategic Development Plan (MSDP)] were selected for their unique project strategies and implementation approaches and being "newto-context" in Bangladesh, including emphasizing improved governance and facilitating bottom-up implementation. In addition, both projects were highly relevant to developing urban water-related service delivery and explicitly facilitated active community engagement. These two key projects, summarized below, were used to frame the semi-structured interviews, but this did not constrain interviewees from talking about other key engagements and activities they had been involved with, which were useful for analysis of the broader context.

Project 1 Second Urban Governance and Infrastructure Improvement Sector Project (UGIIP-II).

The UGIIP-II project commenced in 2011, building on the lessons learned from the original project (UGIIP-I, 2003-2010), which aimed to provide infrastructure development and capacity building training to Pourashava staff in selected secondary cities of Bangladesh including Mymensingh (ADB-Bangladesh report, 2015). Funded by the Asian Development Bank (ADB), this project was designed to improve the functionality of the urban utility service provider, the Local Government 
Engineering Department (LGED), by focusing on developing local infrastructure and improving local governance capacity (ADB-Bangladesh report, 2015). The key emphasis of UGIIPII was to motivate participating Pourashavas to improve their governance functions by ensuring citizen participation, particularly the inclusion of women, the poor and minority groups in Pourashava activities. The UGIIP-II project completion report of 2015, along with an evaluation study undertaken in 2016, supported the design of a third phase, which was under consideration at the time of conducting the interviews (February-July 2017).

Project 2 The Mymensingh Strategic Development Plan (MSDP) (2011-2031).

The MSDP project is one of several long-term initiatives undertaken by the Bangladeshi government, led by the Urban Development Directorate (UDD), and funded by the UN Development Programme (MSDP, 2015). This longterm project aims to ensure basic services are delivered to urban communities, by improving community resilience through increasing formal and informal participation and collaboration within and between government agencies, with non-government organizations (NGOs), and broader civil society. The Mymensingh Pourashava has been actively involved in this project, from the design phase through to implementation, and a key step was the 20-year master plan to boost the Pourashava's capacity to envision the city's resilience. Details of the master plan can be found at http://www.udd.gov. bd/site/publications/3cadb66c-clfb-490f-ba99-b76936365de1/ Mymensingh-Strategic-Development-Plan-MSDP-2011--2031 and at their website, http://www.msdp.gov.bd/. For this study MSDP project is considered as niche due to its different approach (bottom-up planning with numerous consultations with local actors) from the conventional planning approach (top-down) practices in Bangladesh.

Further data collection included face-to-face semi-structured interviews with key stakeholders and several informal group sessions in Mymensingh city. The objectives of these interviews were to identify whether the critical attributes of AG were present and whether these attributes were improving the adaptive capacities to guide Mymensingh's urban water system toward sustainability. Thirty-six semi-structured interviews were conducted in Bangla, a language in which interviewees and the lead researcher are fluent (Bryman, 2004). An interview schedule (Bryman, 2004), including questions, was prepared prior to fieldwork. Interview participants were selected based on their involvement in the Pourashava's water management activities and the interviews explored professional engagement in the industry, capacity-development activities (at an individual or institutional level) to deal with the growing water management crisis (e.g., groundwater depletion, surface water pollution).

The mayor and key actors from the Pourashava management committee were identified as important informant interviewees and were asked to identify other relevant experts in the field, based on the snowball method as described in Creswell (2013). Town-level and ward-level coordination committee (TLCC and
TABLE 1 | Data collection methods.

\begin{tabular}{|c|c|c|}
\hline & Methods & Dimensions \\
\hline \multirow[t]{2}{*}{ Primary data } & $\begin{array}{l}\text { Face-to-face, } \\
\text { audio-recorded, formal } \\
\text { semi-structured } \\
\text { interviews }(n=36)\end{array}$ & $\begin{array}{l}\text { Of the } 36 \text { interviewees, } 14 \\
\text { represented the Mymensingh } \\
\text { Pourashava (municipality) and were } \\
\text { involved with the projects [Second }\end{array}$ \\
\hline & $\begin{array}{l}\text { Informal group } \\
\text { stakeholder } \\
\text { discussions ( } 22 \\
\text { individuals in four group } \\
\text { discussions) }\end{array}$ & $\begin{array}{l}\text { Improvement (UGIIP-II) and } \\
\text { Mymensingh Strategic Development } \\
\text { Plan (MSDP)] and council staff who } \\
\text { are actively involved in the daily } \\
\text { management and implementation } \\
\text { activities within the Pourashava } \\
\text { boundary (e.g the Mayor and } \\
\text { Pourashava representatives). The } \\
\text { remaining participants ( } n=22 \text { ) were } \\
\text { from different organizations including } \\
\text { community committee members, } \\
\text { NGO workers, academics based in } \\
\text { Mymensingh, project personnel } \\
\text { (government and non-government) } \\
\text { based in Dhaka and civil society } \\
\text { activists linked with Pourashava } \\
\text { activities }\end{array}$ \\
\hline Secondary data & \multicolumn{2}{|c|}{$\begin{array}{l}\text { Collation and review of relevant documentation from national } \\
\text { and Pourashava scale policy material, national reports, } \\
\text { relevant project proposals, annual reports, project reports, } \\
\text { committee meeting minutes and reports, workshop } \\
\text { presentation documents, and scientific literature }\end{array}$} \\
\hline
\end{tabular}

WLCC, respectively), members were identified as potential participants and interview schedules differed depending on the activities they were involved in. Fourteen interviewees were directly engaged with Pourashava day-to-day water-related services while the remaining twenty-two were actively involved in different organizations working in water management in Mymensingh and linked with the Pourashava's activities. Interviews were conducted for 45-90 min, but typically lasted $1 \mathrm{~h}$. Similar processes were used to capture data from the interviews (audio recording or, if not recorded due to interviewee preference, detailed notes were taken). After the interviews, the audio recordings were transcribed; if not recorded, the handwritten notes were typed as soon as possible. Summary notes and short memos were also documented as soon as practicable after interviews to capture the researcher's initial thoughts and reflections.

Informal group discussions typically included three or four individuals (in most cases these were people involved in the primary semi-structured interviews) engaging in facilitated discussions with the researcher regarding patterns and trends in the sector. The informal settings meant there was no provision for audio recording, but detailed notes were taken, focusing on key concepts discussed and relevant future directions regarding the sector (Table 1). Notes of these informal sessions were taken in Bangla, transcribed and then translated into English for further analysis.

The semi-structured interviews were undertaken by asking interviewees to reflect on the scales of involved institutions and linkages between them, the different actors involved and the 
nature of their engagements and networks, the role of bottomup initiatives (if any) and key further developments and changes arising as a result of the projects (UGIIP-II and MSDP). These questions, however, did not constrain interviewees but rather encouraged participants to refer to other key projects/programs of change that were underway. Transcribed interview data were coded and analyzed to aggregate into themes and were subsequently interpreted to develop understanding of adaptive governance mechanisms in context. In light of the ACA framing of the overall empirical approach, the materials were analyzed to capture the following main themes: changes within the governance regime identified through institutional reforms and evolving actor engagements via multi-level interactions; evidence of bridging of gaps by stakeholders through collaborative efforts; and new network building and capacity development initiatives. Here, evidence included project/Pourashava reports, newspaper and newsletter coverage. Secondary data analysis was then compared against interview data with cross-referencing and validation.

\section{RESULTS AND DISCUSSION}

\section{The Evolution of Urban Water Governance in Mymensingh}

Mymensingh Pourashava was established in April 1869 and recognized by the British Government for its regional importance; however, the Pourashava remained underdeveloped for a long period of time (e.g., during the Pakistan and early Bangladesh periods see Yasmin et al., 2019), unlike other secondary cities in Bangladesh, such as Bogra. Jessore, Kustia. Reasons for this include political turmoil (i.e., conflicts with Pakistani rule and then being a newly independent country with a broken economy), the national attention required for flood management and food security, particularly in rural areas, and finally the urban bias where Dhaka and other larger cities received investment whereas other cities were left behind due to focus on metropolitan development (Yasmin et al., 2018). The concept of urban bias explains why larger cities are favored by the government due to their exploitable resources and important attributes for political control (see e.g., Rondinelli et al., 1983; Owusu, 2005). Although urbanization began in Mymensingh as far back as the 1980s, and has doubled over the past 5 years, there were few strategies or planning documents aimed at developing Mymensingh city before 2005 (MSDP, 2015; Yasmin et al., 2018). Mymensingh Pourashava is governed by the Pourashava Parishad (council) under the Pourashava Act (2009), which consists of twenty-one wards with elected members from each ward (optional local administrative level in a city in Bangladesh for electoral purposes). Table 2 presents a timeline to showcase different socio-political contexts and governance approaches from the initiation of Mymensingh Pourashava in 1893 to 2017. This timeline indicates changes in key legislations, polices and plans that increase complexity in the hydro-social contract, i.e., the unwritten contract that exists between the public and the government for the centralized provision of water services (Turton and Ohlsson, 1999).
In terms of urban water services, as of 2017, Mymensingh Pourashava had the capacity to supply one-third of its total water demand, covering $\sim 15$ percent of total households (MSDP, 2015). To supplement water supplies, households typically draw from individual or shared tube-wells and street hydrants, increasing water coverage to 46 per cent of the total population, including informal (slum) communities (MSDP, 2015). For sanitation, approximately 93 percent of the Mymensingh Poursharva population use some form of latrine, including septic tanks, ventilated and pit latrines (MSDP, 2015).

\section{Formalizing and Developing the Urban Water System (1893-1995)}

Mymensingh has a long history of formalized urban water practices reflecting its regional importance during the British colonial period. Analysis of media and other secondary data (i.e., collected documents from the Pourashava) revealed that the urban water system in Mymensingh was first established in 1893, soon after that in Dhaka (1878). Formalization of the urban water system in Mymensingh was initially driven by the British colonial administration for subcontinental sanitary reform, similar to Dhaka's urban water (Yasmin et al., 2018). The death of the then King's wife, who succumbed to a cholera outbreak, prompted the King to turn his attention to delivering good-quality drinking water. The King donated a significant amount of money to build waterworks (one water treatment plant and a piped network for small coverage and a few street scale hydrants, here referred to as a niche project/innovation). The urban water niche was named "Rani Rajeshwari Devi (RR)" waterworks, to commemorate the King's efforts and the regime's focus on delivering improved water quality and sanitation and reducing mortality.

The empirical case data (interview and media) reveal that after the establishment of the RR waterworks, Brahmaputra River was the only source for extracting water. However, due to the high cost posed by technical difficulties and maintenance, and the lack of sufficient storage capacities, development of this niche was unsuccessful despite pressure from the regime. As a result, the Pourashava closed the water treatment plant in 1966. The limited Pourashava water supply records indicate that the total water supply infrastructure included $42 \mathrm{~km}$ of pipeline, 782 water connections (largely domestic and a few commercial), and 315 street hydrants with five overhead tanks. An interviewee (Pourashava staff member) inferred that the water supply coverage during this period was only for a number of local elites.

The closure of the urban water niche in 1966 resulted in the introduction of a new actor in the urban water governance system, when the Department of Public Health and Engineering (DPHE), a central agency under the Ministry of Local Government, Rural Development and Cooperatives (MoLGRD\&C), similar to the Local Government Engineering Department (LGED) and established in 1953, took control of drinking-water supply management in Mymensingh city. The DPHE played a significant role in developing the urban water system until 1972, after which the political turmoil in the country weakened its programs and services. After 
TABLE 2 | The evolution of governance approaches and actor clusters influencing Mymensingh urban water governance.

\begin{tabular}{|c|c|c|c|c|c|}
\hline \multirow{3}{*}{$\begin{array}{l}\text { Socio-political } \\
\text { context }\end{array}$} & \multirow{3}{*}{$\begin{array}{l}\begin{array}{l}\text { Period of } \\
\text { development }\end{array} \\
\text { Formalizing and } \\
\text { developing the } \\
\text { urban water } \\
\text { system } \\
\text { (1893-1995) }\end{array}$} & \multicolumn{2}{|r|}{ Key legislations, policies, and plans } & \multicolumn{2}{|c|}{ Shifts in urban water governance agenda and key actor-clusters } \\
\hline & & $\begin{array}{l}\text { Central/national } \\
\text { scale }\end{array}$ & $\begin{array}{l}\text { - Water supply and sanitation ordinance, } 1963 \\
\text { - Bangladesh Local Councils and Municipal } \\
\text { Committees (Amendment) order } 1972 \\
\text { - Drinking water standard in } 1984\end{array}$ & \multirow{2}{*}{$\begin{array}{l}\text { Central agencies (i.e., DPHE and LGED) control } \\
\text { Pourashava's activities and led to develop an } \\
\text { urban water system guided by state and donor } \\
\text { organization (ADB) with a focus on water } \\
\text { supply and drainage }\end{array}$} & \multirow{2}{*}{ Citizens } \\
\hline & & $\begin{array}{l}\text { Local Government } \\
\text { Implementation } \\
\text { (LGl) scale }\end{array}$ & $\begin{array}{l}\text { - Bengal Municipalities Act, 1864, } 1938 \\
\text { - Local Self-Government Act, } 1885 \\
\text { - Local Government Loan Act, } 1879\end{array}$ & & \\
\hline \multirow[t]{5}{*}{ Bangladesh } & \multirow[t]{2}{*}{$\begin{array}{l}\text { Evolving policies } \\
\text { and institutions } \\
\text { (1996-2010) }\end{array}$} & $\begin{array}{l}\text { Central/national } \\
\text { scale }\end{array}$ & $\begin{array}{l}\text { - Environmental Conservation Act' (1995) and rules } \\
\text { (1997) } \\
\text { - Housing Act } 1996 \\
\text { - National policy for Drinking water supply and } \\
\text { sanitation, } 1998 \\
\text { - National Water Policy, } 1999 \\
\text { - Participatory Guidelines for water-based projects } \\
\text { (1995/1998/2000) } \\
\text { - Millennium Development Goals (MDGs), } 2000 \\
\text { - Water supply and sanitation baseline survey, } 2003 \\
\text { - National Sanitation Strategy, } 2005 \\
\text { - Hygiene Strategy, 2005 } \\
\text { - Water and Sanitation Sector Development } \\
\text { Plan (2005-2015) }\end{array}$ & \multirow[t]{2}{*}{$\begin{array}{l}\text { Donor organizations' influence and investment } \\
\text { continued to shape state-led formal urban } \\
\text { water systems, although DPHE fails to } \\
\text { contribute and Pourashava took charge. } \\
\text { However, during this period there was an } \\
\text { emerging service delivery role for NGOs around } \\
\text { water supply and sanitation along with } \\
\text { increasing attention toward environmental } \\
\text { activist around river water pollution. There are } \\
\text { no opportunities for citizen participation } \\
\text { although there were policies and strategic } \\
\text { direction }\end{array}$} & \multirow[t]{2}{*}{ LGRD\&C } \\
\hline & & $\begin{array}{l}\text { Local government } \\
\text { implementation } \\
\text { (LGI) scale }\end{array}$ & $\begin{array}{l}\text { - Upzilla Parishad Act of } 1998 \\
\text { - Zilla Parishad Act, } 2000 \\
\text { - Pourashava Act } 2009 \\
\text { - Citizen Charter } \\
\text { - Pourashava Vision }\end{array}$ & & \\
\hline & \multirow[t]{3}{*}{$\begin{array}{l}\text { Redefining roles } \\
\text { and policy goals } \\
\text { (2011-2017) }\end{array}$} & $\begin{array}{l}\text { Central/national } \\
\text { scale }\end{array}$ & $\begin{array}{l}\text { - Bangladesh Water Act, } 2013 \\
\text { - Sector development plan (2011-2015) } \\
\text { - National Water Supply and Sanitation Strategy, } \\
2014 \\
\text { - Gender equity strategy in } 2015\end{array}$ & \multirow{3}{*}{$\begin{array}{l}\text { Donor organization continue to influence and } \\
\text { other central agencies (i.e., UDD) came for } \\
\text { collaborative activities for shaping urban water } \\
\text { governance regime as multi-level and } \\
\text { participatory. NGOs become development } \\
\text { partners and continue to work on } \\
\text { soft-approaches. Innovation in governance and } \\
\text { planning (i.e., UGIIP and MSDP) facilitated } \\
\text { citizen participation in decision-making and } \\
\text { further to influence regime activities (e.g. town } \\
\text { level committees for decision-making) }\end{array}$} & \multirow{3}{*}{$\begin{array}{l}\text { LGRD\&C, } \\
\text { MoWR \& } \\
\text { MoH\&PW }\end{array}$} \\
\hline & & $\begin{array}{l}\text { Local government } \\
\text { implementation } \\
\text { (LGl) scale }\end{array}$ & $\begin{array}{l}\text { - Pourashava Gender and Poverty Reduction } \\
\text { Action Plan } \\
\text { - Mymensingh Strategic Development } \\
\text { Plan (2011-2031) }\end{array}$ & & \\
\hline & & & & & \\
\hline
\end{tabular}

LGRD\&C, Ministry of local government, rural development and co-operatives; MoWR, Ministry of water resources; MoH\&PW, he Ministry of housing and public work; CDMP, Comprehensive disaster management program; UNDP, United nation development program; DPHE, Department of public health and engineering; LGED, Local government engineering department; UDD, Urban development directorate; TLCC, Town-level coordination committee; WLCC, Word level-coordination committee. 


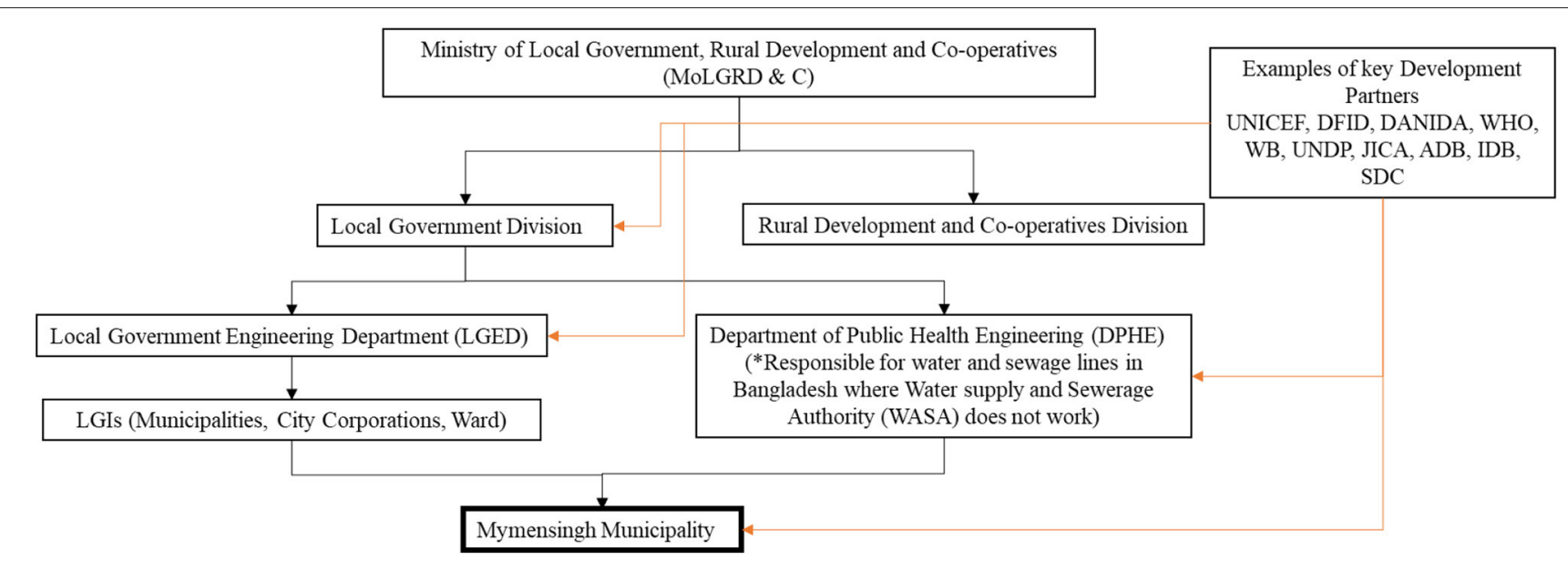

FIGURE 3 | Relevant organizational hierarchy at national and local context. Further details on their respective roles, responsibilities and approaches are presented in Table 2.

the country secured independence in 1971, the Bangladesh Government sought international support to improve public health outcomes. Based on the recommendations of international development organizations, the water supply in Bangladesh, including Mymensingh, moved to groundwater-based systems (IBRD, 1972). At this time the water management regime shifted and DPHE as the dominant actor started to install tube-wells all over the country, including in Mymensingh Pourashava. This led to the development of the current urban water system in Mymensingh using a groundwater-based water supply system. The donor agency, Asian Development Bank (ADB) assisted in this development through financial and technical support to DPHE and became a key actor (Table 2).

While the broader regime focus was on developing smalltown water supply and sanitation, installing tube-wells, and building a small, piped network became the dominant activities undertaken by DPHE. DPHE did not engage with the Pourashava to build their capacity. As a result, these niche projects failed to provide the anticipated outcomes to develop institutional and administrative capacity and similar failures were also observed in other Pourashavas, leading the $\mathrm{ADB}$ and the Government of Bangladesh to recognize the need to involve Pourashavas in such activities to improve their capabilities to deliver basic services, such as water supply. This prompted the formulation of a new policy for urban management (1994) (Table 2) and shifted regime focus to strengthening Pourashavas' organizational and staff capacities so that they could deliver water and sanitation services without DPHE involvement in implementation activities (ADB, 2015). However, there was no significant activity identified by the interviewees during the research period that relates to the "capacity" building issue indicated by the failed niche projects due to failure of the initiatives.

During the period post 1994, the actor clusters responsible for urban water governance involved the Pourashava, the DPHE, the LGED (as the controlling authority for Pourashavas) (Figure 3) and the ADB. The Pourashava, although the key actor, lacked the capacity to deliver water and sanitation services and the DPHE with the LGED became dominant actors in water and sanitation services. However, the central agencies, the DPHE and the LGED, had a different political and institutional ideology. The DPHE was focused on developing the water supply system and a few toilets (both public and shared community latrines) as part of the national public health agenda, while the LGED focused on strong centralized influence over Pourashavas' administrative and financial activities (ADB, 2015). Figure 3 represent a schematic of these organisations' administrative hierarchy across different scales and among with responsible agencies. Further details on their respective roles, responsibilities and approaches are presented in Table 2. Additionally, during this period there was little coordination between these two central agencies, which led to conflicts over decision-making and authorization of urban water management in Mymensingh. Furthermore, additional pressures and influence were exerted by the international development partners (e.g., the $\mathrm{ADB}$ ), which further shaped urban water governance strategies in Mymensingh in order to improve local governance capacity, which is discussed in detail in Section Increasing Adaptive Capacity in Mymensingh's Urban Water System.

\section{Evolving Policies and Institutions (1996-2010)}

Although there have been policies directed at improving the Pourashavas's internal capacity (organizational and staff) (see Table 2), the on-ground reality did not reflect such policy implementation. With capacity-building in mind, the government continued to release other relevant policies as stated in Table 2 to reduce the policy gap in the capacity of Pourashavas (ADB, 2015). Following this shift in policy, the regime supported advancing political decentralization and conferred a level of financial authorization (2004) onto local government institutions (LGIs) (Bangladesh Local Government Acts and Rules, 2015; 
Table 2). Such regime changes opened opportunities for political decentralization, though the change remained largely inactive:

\begin{abstract}
The Government has long been aware of the rapid pace of urbanization and the associated physical, economic, and social problems, it has not yet been able to approve a comprehensive urban policy. The Urban Management Policy Statements (1994 and 1999) prepared by the Local government Division (LGD) emphasized that all Pourashavas' should have adequate personnel and financial strength, provide and maintain infrastructure, implement land use plans, address poverty, ensure participation, and involve the private sector. These policy statements, however, were not enacted (ADB, 2009, p. 8).
\end{abstract}

This continuing gap in policy translation was also reflected in interviewees' examples of other failed niche projects in Mymensingh and other Pourashavas. The secondary city water supply and sanitation project (2006-2010) in Mymensingh was designed and implemented by the DPHE with support from the $\mathrm{ADB}$, where Mymensingh Pourashava was largely responsible for maintaining the project. However, the Pourashava failed to continue it, because the staff were not trained enough to run and maintain the technology that the DPHE installed. The same thing had happened in other Pourashavas where the project had been implemented.

This recurring failure of niche projects indicated that the regime had not provided actors with the knowledge and technical skills required for the projects' success (i.e., delivery of an installed and functioning water supply system). This meant that the anticipated outcomes were never going to be achieved. However, interviewees pointed out that they had raised these issues with their higher authority and donor agencies (i.e., the $\mathrm{ADB}$ ), which led to several joint studies (central agencies and $\mathrm{ADB}$ ). The findings from the studies shaped the formulation of the Pourashava Act (2009). This Act is focused on improving the capacity of local institutions, Pourashavas (individuals and organizations); to build the skills and capacity needed to ensure a smooth delivery of basic water supply and sanitation services. Interview participants had very positive responses toward the Pourashava Act (2009) and indicated it had influence over their conventional management approach. The interviewees pointed out that with this Act, the Pourashava and other Pourashavas were no longer under the control of the DPHE and/or the LGED. Rather, they felt empowered by having a platform to make their own context-based decisions while enjoying some form of financial autonomy. Here financial autonomy reflects how Pourashavas have authorization to make investments, approve annual budgets, revise/levy tax rates/fees/tools, and undertake projects from their own funds, or how they can directly receive grants from donor organizations:

Before this Pourashava Act, we feel like we are middle of these two central agencies (DPHE and LGED). These two do not talk to each other and there is no clear instruction of what their authority over our initiatives. Most of the time we cannot meet our deadline as there are always dilemmas on signatory authorization. (Senior manager, Mymensingh Pourashava) [Interviewee quote 1].
The formulation of the Pourashava Act (2009) was also the outcome of broader regime change experienced by the water sector as it followed international discourses on the adoption of IWRM $^{1}$ into the National Water Policy (NWP) (1999) and other policies (see Table 2). Indeed, one interviewee stated that with the enactment of the Environmental Conservation Act (ECA) in 1995 and rules in 1997, they started to address the "Brahmaputra River pollution and untreated sewage dumping into and on the banks of the river" and raised their voices against pollution. As part of their initiative, they organized rallies and seminars and questioned the Pourashavas' capacity to resolve such issues. This indicates the emergence of environmental activists as another actor cluster (see Table 2) and they gained greater influence over the approach to urban water governance in recent years.

This period saw regime-driven changes (policy and administrative changes) in urban water governance in Mymensingh, and for the first time in history, Pourashavas were engaged with the decision-making processes and had financial autonomy. This period also experienced critical engagement of other actors, including environmental activists who have had some influence over urban water systems. Overall, this time period demonstrated: (i) an evolution in the policy and institutional contexts associated with urban development and improving urban water service delivery, and (ii) recognition that the capacities of local state agencies required attention. Moreover, new discourses, interests and an emerging social movement toward environmental conservation (i.e., drinking water security and quality; restoration of river quality, saving urban wetlands and green spaces) started to influence national strategic directions and policy goals, despite strong centralized control.

Together, these policies and innovative strategic guidance supported the development of other niche projects that are closely related to the urban water niche. In light of these regime changes, different development partners began designing and implementing water and sanitation projects aimed at small town developments and reducing river water pollution. This seeded the initial the ADB-funded UGIIP project, a niche project in Mymensingh and forty-seven other Pourashavas. The project was unique and new-to-context (i.e., in a secondary city) for Bangladesh due to its significant attention toward improving Pourashavas' governance capacity in leading water supply and sanitation services as well as keeping river water clean by developing drainage networks to manage sewerage and stormwater discharge.

\section{Redefining Roles and Policy Goals (2011-2017)}

The evolving urban water governance regime in Mymensingh, resulting from key policy and institutional changes, prompted major governance reforms and enabled diverse actors' engagement at multiple levels of implementation. The Pourashava Act (2009) and UGIIP project implementation in Mymensingh city led to innovative strategies to drive a shift toward a hybrid structure of governance, which refers

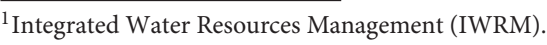




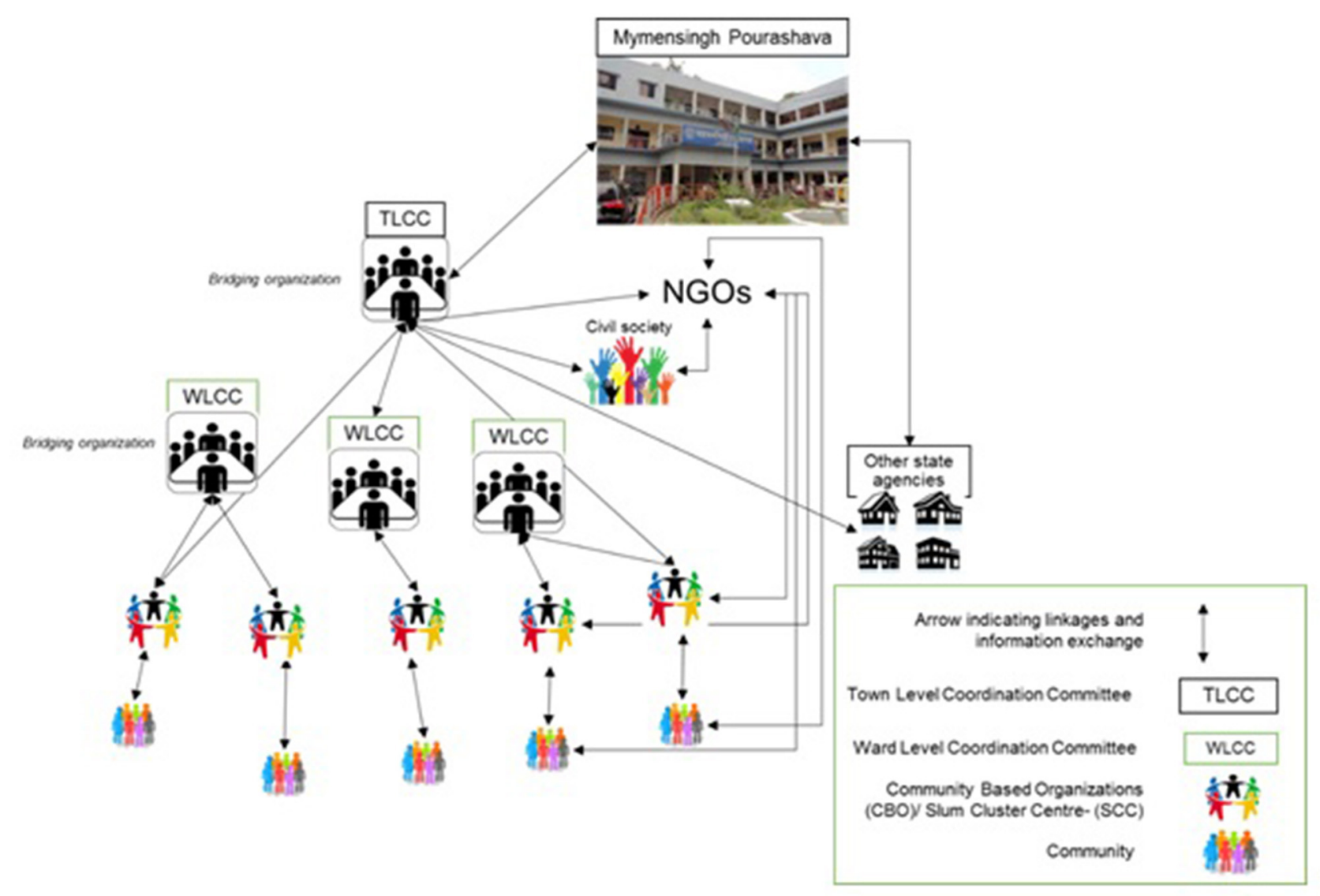

FIGURE 4 | Schematic showing networks of actors and actor clusters (town level coordination committee-TLCC and ward level town level coordination committee-WLCC) and their scales in Mymensingh city development initiatives. These actors clusters are project based (i.e., come together to deliver a specific project usually funded via an external international stakeholder), however as found through this research they play a critical role in forming a hybrid governance structure and in influencing water management decision-making. Further details on their respective roles, responsibilities and approaches are presented in Table 2.

to the combination of aspects of hierarchical, market and network approaches (Van de Meene et al., 2011). Several scholars indicated that this hybrid structure is likely to be more available in the complex real-world situation (Pierre and Peters, 2000; Meuleman, 2008) and has more potential to deliver sustainable outcomes than traditional top-down approaches (Kooiman and Jentoft, 2009; Pahl-Wostl, 2009; Van de Meene et al., 2011). Van de Meene et al. (2011) explained that the hierarchical approach (shown in Figure 3) in the hybrid structure is beneficial to supporting the formal administrative authorization, political leadership and sanctions, whereas the network approach (prompted by developing small groups at town, ward and community level, as shown in Figure 4) is beneficial for ensuring flexibility in implementation and supporting informal activities facilitating collaboration, learning and innovation, while the market governance approach facilitates efficient resource use, providing incentives and stimulating industry participation.

Through our analysis, we captured the real-world operation of this hybrid structure of governance in Mymensingh involving the engagement of several actors and agencies at the national/central scale (i.e., DPHE, LGED, DoE ${ }^{2}$ ) and at city-scale/local scale (i.e., the Pourashava, town and ward level coordination committees (TLCC, WLCC), all functioning through an institutional hierarchy with some administrative decentralization (see Figure 4 for details). Here the decentralized schemes have some form of polycentric characteristics, ${ }^{3}$ as they transfer decision-making and financial autonomy to local scale actors by embedding them in the Pourashva's management system along with other relevant actors (i.e., DPHE, LGED) (see Table 2; Figures 3, 4).

The networks or actor clusters (Town and Ward level committees and community-based organizations) typically consist of local community members and representatives from NGOs, and environmental activists. This shift to a hybrid

\footnotetext{
${ }^{2}$ Department of Environment under the Ministry of Environment, Forest, and Climate Change.

3 "Polycentric characteristics" refers to having many centres of decision making in a resource governance structure. See further Cinner et al. (2012), Huntjens et al. (2012), and Yasmin et al. (2019).
} 
governance structure in Mymensingh is creating an increasingly complex dynamic among the actors and in institutional arrangements. This shift is new in the context of local government agencies in Bangladesh and has opened a platform for participatory decision-making by forming new networks of diverse actors (see Table 2; Figure 4). However, shifting toward a hybrid and polycentric governance structure in Mymensingh now raises the questions if and how these practices are contributing to developing adaptive governance capacity. This requires further analysis of the governance structure, relevant actor clusters and their activities at multiple levels of implementation.

In this context, the Mymensingh Strategic Development Planning (MSDP) was established as a niche project (20112015). The MSDP was a pilot, designed to facilitate national collaborative efforts to increase the community's capacity to engage in future city planning. The MDSP project drafted a twenty-year master plan to guide sustainable development in Mymensingh. Within the data collection period of this research, interviewees spoke highly of these two projects (MSDP and Second Urban Governance and Infrastructure Improvement project), identified the dawn of a new period of development for Mymensingh city, and indicated a key focus on improving governance capacity for local actors with greater influence over the delivery of water sanitation services in Mymensingh. The following section will further analyse and discuss how related innovation and strategic guidance, emerging from the experiences gained during implementation of these two key niche projects (MSDP and UGIIP-II) is contributing toward developing adaptive capacity, using the ACA framework. This will build an understanding of what (else) is needed for advancing sustainable urban water management in Bangladesh.

\section{INCREASING ADAPTIVE CAPACITY IN MYMENSINGH'S URBAN WATER SYSTEM}

As outlined above, significant changes have been observed in the Mymensingh regime since the establishment of formal urban water system in 1893. Although major changes captured after the implementation of the second Urban Governance and Infrastructure Improvement (UGIIP-II) project and Mymensingh Strategic development plan (MSDP) project, where the contribution and influence of the transnational actors (e.g., ADB, UNDP) is very prominent. The identified niche projects, UGIIP and MSDP were designed and implemented by following the strategic and financial guidance developed by these transnational actors to improve the institutional and actors' capacity at the local level. Table 3 presents the identified synergies as well as $s$ the tensions present in the two projects related to their vision, implementation approach, key focus and the nature of the lead actors' involvement. As mentioned earlier, the activities implemented through UGIIP and MSDP have driven a shift toward the development of a hybrid system that also shows some polycentric characteristics, creating opportunities for participatory and network activities through nurturing by bridging organizations (who act as mediators to promote connection and participation) and the resulting enhanced leadership capabilities. These features align with attributes in the ACA framework and act as enablers to improve adaptive capacities to advance sustainable urban water management (SUWM). In light of such understanding, analysis of these enablers is extended below with discussion of how they are contributing to an increased level of adaptive capacity within Mymensingh's urban water governance system to support a sustainability transition.

\section{Hybrid Governance With Polycentric Characteristics}

The hybrid and polycentric governance structure in Mymensingh Pourashava have significant influence over the relevant institutions and actor interactions at both central and local levels and offers critical space for their participation in decisionmaking processes. According to interviewees, new actor clusters (i.e., TLCC/WLCC) are involved in decision-making, broadening their capacity for implementation of both UGIIP and MSDP (see Table 3) through collective efforts. The ACA framework indicates that such participation is important for integrating the polycentric governance approach and emphasizes this as an alternative to traditional top-down, state-driven approaches. Polycentric governance develops the capacity of non-state actors and ensures their participation in decision-making at multiple scales of implementation (Clark and Semmahasak, 2013; Newig and Koontz, 2014; Azhoni et al., 2017; Yasmin et al., 2019).

In Mymensingh, such emerging polycentric governance in the hybrid structure provides broader opportunities for nonstate actors to be involved in Pourashava activities and to adopt a participatory approach for developing a shared vision and facilitating learning outcomes. The ACA framework identifies these as key adaptive attributes for advancing SUWM. For example, during the interviews, Pourashava staff indicated that when developing an underground drain, the implementation team waited for the collective consent of the TLCC. If the project design was not approved by the TLCC, they could not start implementation, as the community would not accept it. Pourashava staff added that communities know their waterlogging situation and the causes of it best as they have been living there for a long time, while Pourashava staff are not necessarily from the local community (Pourashava service requires transfers from one Pourashava to another over their service period). This further indicates the importance of the local knowledge (tacit knowledge) incorporating into decisionmaking practices.

Further, interviewees indicated that this hybrid governance structure and its polycentric nature created an opportunity for local communities to participate and exchange information and raise awareness about mechanisms and practices to help the city of Mymensingh become more sustainable. For example, regular activities such as yard meetings (small community groups meeting in front of their houses), which are facilitated by local NGOs or more often by the community leaders with a small group of people (12-15), were used to share updates from the 
TABLE 3 | Synergies and tensions between the UGIIP and MSDP projects in Mymensingh.

\begin{tabular}{|c|c|c|c|c|}
\hline Criteria & UGIIP project & MSDP project & Synergies & Tensions \\
\hline $\begin{array}{l}\text { Implementation } \\
\text { period }\end{array}$ & $\begin{array}{l}\text { 2009-2014 (Phase-II) (*Phase-III will } \\
\text { commence from 2017) }\end{array}$ & 2011-2015 & $\begin{array}{l}\text { Share diverse range of resources delivered } \\
\text { though the projects' period (i.e., different } \\
\text { reports and learning outcome) } \\
\text { A common pool of local actors (i.e., MDSP } \\
\text { identified potential actors those are already } \\
\text { involved with the UGIIP project therefore, } \\
\text { already developed some form of capacity in } \\
\text { understanding complex problems within } \\
\text { urban boundary) }\end{array}$ & $\begin{array}{l}\text { With UGIIP project activities already in execution, it } \\
\text { was difficult for the MDSP team to facilitate } \\
\text { communities' involvement for identifying disaster } \\
\text { risk related activities in city planning, not the } \\
\text { infrastructural development for city development }\end{array}$ \\
\hline Lead actors & $\begin{array}{l}\text { Local government engineering } \\
\text { department (LGED), department of } \\
\text { public health and Engineering (DPHE) } \\
\text { and Mymensingh Pourashava. }\end{array}$ & $\begin{array}{l}\text { Comprehensive disaster management } \\
\text { project (CDMP) - UNDP Bangladesh and } \\
\text { urban development directorate (UDD) }\end{array}$ & & $\begin{array}{l}\text { Different agencies with different mandate make it } \\
\text { difficult to collaborate }\end{array}$ \\
\hline Vision & $\begin{array}{l}\text { Improved municipal service delivery } \\
\text { and urban governance in project and } \\
\text { strengthen pro-poor and } \\
\text { gender-responsive urban governance }\end{array}$ & $\begin{array}{l}\text { Developing a 20-year of a master plan for } \\
\text { Mymensingh Pourashava and surrounding } \\
\text { areas to build Pourashava's capacity to } \\
\text { envision their city's future resilience }\end{array}$ & $\begin{array}{l}\text { Emphases on developing Pourashava's } \\
\text { governance capacity to be able to deliver } \\
\text { improved services (i.e., water supply and } \\
\text { sewerage/storm water management, } \\
\text { establishing water reservoir for water security) }\end{array}$ & $\begin{array}{l}\text { UGIIP project largely deal with hard-approach } \\
\text { (building drains, piped networks) whereas MSDP is } \\
\text { more onto soft-approaches (planning and } \\
\text { community resilience). While there are scopes for } \\
\text { complement, however in reality UGIIP already is in } \\
\text { implementation whereas MSDP developed a master } \\
\text { plan that awaiting formal approval, therefore it is } \\
\text { difficult to support each other's implementation } \\
\text { processes }\end{array}$ \\
\hline $\begin{array}{l}\text { Implementation } \\
\text { approach }\end{array}$ & $\begin{array}{l}\text { Sectoral, participatory and inclusive } \\
\text { governance approach toward } \\
\text { communities' representation in } \\
\text { decision-making and authorization }\end{array}$ & $\begin{array}{l}\text { Bottom-up urban planning approach with } \\
\text { wide-range of the community to point out } \\
\text { the key problem and identify possible } \\
\text { solutions }\end{array}$ & $\begin{array}{l}\text { Both of the projects instigate participatory } \\
\text { learning and implementation }\end{array}$ & $\begin{array}{l}\text { UGIIP project has some pre-planned activities that } \\
\text { were little different from the MSDP master plan, } \\
\text { resulting in confusion over implementation }\end{array}$ \\
\hline Focus & $\begin{array}{l}\text { Developing partnership between and } \\
\text { among govt., development partners } \\
\text { and other key sector stakeholders to } \\
\text { broaden government and national } \\
\text { ownership over public sector policy } \\
\text { and resource allocation within the } \\
\text { sector }\end{array}$ & $\begin{array}{l}\text { Developing communities' resilience } \\
\text { through increasing formal and informal } \\
\text { participation and collaboration between } \\
\text { government efforts with other government } \\
\text { agencies and also with other } \\
\text { non-government organization and civil } \\
\text { society for sustainable development of } \\
\text { urban areas and ensure basic service } \\
\text { delivery to the people }\end{array}$ & $\begin{array}{l}\text { Developing partnership between and among } \\
\text { diverse range of stakeholders aiming to ensure } \\
\text { equal distribution and access to resources }\end{array}$ & $\begin{array}{l}\text { UGIIP is focused on developing capacity of the state } \\
\text { actors whereas MDSP is focusing on developing } \\
\text { communities' capacity to be involved in risk } \\
\text { reduction processes }\end{array}$ \\
\hline
\end{tabular}


TLCC/WLCC member groups and contributed to increasing community awareness about personal and environmental health. These yard meetings became a source of information exchange and sharing in issues like sanitation and hygiene, reproductive and child health among others are discussed, which with the help of TLCC/WLCC groups prompted an aspiration for healthy living standards, including in informal settlements (slums). Figure 4 clearly indicates the nature of the relevant actors' participation in the formal and informal governance processes, and how these connected actors are contributing to the flow of information and knowledge exchange across them. For example, TLCC activities are fed through the discussion and information exchange in WLCC meetings. Such exchange of information through these types of overlapping committees is necessary for integrating bottom-up thinking with the traditional topdown strategies, a development that is important for sustainable delivery of services (Biggs et al., 2013; Larson et al., 2013; Ahammad et al., 2014; Azhoni et al., 2017).

Furthermore, the overlapping membership and integration (sharing) of knowledge are important adaptive attributes (Figure 4) that are critical for strengthening communities' ongoing capacity to support a sustainable system as captured in the ACA framework (Yasmin et al., 2019). This integration of knowledge builds management capacity and initiates innovative ideas. For example, an interviewee pointed to a specific location in the city where the drainage system was designed and developed using input received from the local community that reduced the problem with stagnant water. Another example, provided by another interviewee, related to the installation of submersible pumps for a shared water supply facility in a slum, an idea that came from that slum community, as they were aware that finding a suitable space for installing tube-wells was critical in densely populated areas such as slums. While these innovative ideas might not solve at once the problems associated with urban water services delivery in Mymensingh, they indicate steps toward increasing the capacity of the relevant communities to think about alternatives suited to their socio-ecological context. These dialogues also have the potential to strengthen communities' self-organizing capacity and to develop trust among state and non-state actors. Self-organizational capacity and trust were identified in the ACA framework as important adaptive attributes.

Prior to the governance shift to a hybrid and polycentric structure, the Pourashava council (consisting of the mayor and councilors) under the central agency LGED had sole access to, and authorization over, resource distribution and management (see Figure 3). Although the success of the council largely depends on the elected members' leadership capabilities, interviewees raised some criticisms. They mentioned that there was distrust and differences in political beliefs and agendas among the elected members and the local state actors, which often led to conflict in decision-making. The communities were disconnected from the decisionmaking process which raised distrust and some accountability issues between communities and local state actors including elected members. This is illustrated by the quotes from interviewees below:
Before these committees (TLCC/WLCC), the Pourashava staffs always made excuse for their bad services. More often they did not deliver the promised services and some demanded bribe. Now things are changing and Pourashava staffs are changing their behaviour. (Local community member) [Interviewee quote 2].

Our mayor's door is always open for us. We can enter his office whenever we want and make complaint about the Pourashava services. Before him, no other Mayor opened this door for us. (Social activist, Mymensingh) [Interviewee quote 3].

Including different level actor clusters (TLCC/WLCC) within the Pourashava governance structure created these opportunities for broader community participation and increased the chance for local actors to raise their voices against the issues of distrust and lack of accountability. This also noted by the other government agencies such as urban development directorate, disaster management bureau at national scale utilizing these actors' cluster for their project implementation (i.e., MSDP). A couple of interviewees mentioned the TLCC's mandate of producing yearly report cards and citizen charters which should be displayed in the Pourashava premises in order to improve accountability and visibility:

Citizens should know what we are doing otherwise they will not be convinced. They elected us (mayor and ward councillors) for doing something beyond their expectation to change (in a positive way) the current scenario. They want to see the future where we can provide the quality services to the citizen. (Ward Councillor, Mymensingh Pourashava) [Interviewee quote 4].

\section{Bridging Gaps and Steering new Network Formation}

The TLCC and the WLCC were identified in this research as bridging organizations (i.e., as an enabler that promotes connection and participation across different organizations and individuals) and were referred to as a "timely" and "useful" initiative by interviewees.

\footnotetext{
Nowadays we do not always bother Pourashava people, they have lots to do, when there are blockages and dirt in our drains, we try to clean them ourselves so that natural drainage can work, otherwise it simply starts to overflow and become all smelly and a breeding place for mosquitos and pollutes our environment. (Local community member) [Interviewee quote 5].
}

These committees achieved some successes in bringing different actors to a single platform to discuss and agree upon viable options to address their problems in relevant city-building activities. In analyzing the critical interactions and connections at multiple scales, as presented in Figures 3, 4, it is evident that these actor clusters are crucial, first for stimulating new linkages; second, for strengthening the overall capacity for knowledge sharing and accessing resources; and finally for promoting collective efforts through formation of new actors' groups/networks (both formal and informal). All of these are important adaptive attributes, identified by the ACA framework, 
to encourage co-production of knowledge (defined as iteration of knowledge specific to the local context, generated and utilized by the local actors) for enabling adaptation strategies and to reduce vulnerabilities (Kuzdas et al., 2015; Sowman and Raemaekers, 2018). A community member's comments on their own efforts with resource use and maintenance indicate an increase in communities' responsibilities to reduce vulnerability and uncertainty:

The TLCC acts as a guide for our community. Together we identify problems, seeks necessary solutions, discuss the barriers and advocate on how to overcome those barriers. (A leader of the TLCC and Mymensingh Pourashava) [Interviewee quote 6].

I am a member of TLCC and not a yes person. I always say what I believe will bring good for my city. I will not allow throwing our dirt in drains anymore, now I understand we are responsible for our actions. I always raise my voice in the meetings (TLCC) against all sorts of pollution problems. (Civil society activist) [Interviewee quote 7].

The TLCC is referred to as a "mini-parliament" by interviewees, where communities feel empowered and aware of their city's development activities.

At the time of interviewing, the TLCC was headed by the mayor and included thirty-three diverse professional groups (e.g., teachers, journalists, NGO professionals, other state authority representatives including the Pourashava administrative head and ward councilors), and lower income group representatives (a member of the slums group). The TLCC often discusses and frames recommendations regarding the diverse issues influencing Mymensingh city development. This includes the mode of water supply (piped water, tube-well, or submersible pumps) and coverage, drainage system design and development, waste disposal methods and overall environmental sustainability. For example, improving the drainage system to develop a solid waste disposal system involved state and non-state actors (three local NGOs, one international NGO and one research and education institution). While the TLCC guided the overall collaboration, this initiative provided a significant example of new niche innovation. Through this collaborative intervention, new organic manure from sewerage waste was developed for the local farmers; a new market linkage was established and a connection between rural and urban development was secured.

The actor clusters (TLCC/WLCC/community-based organization) were very prominent and active during the UGIIP project implementation period. However, they became less productive and subsided after the project completed its second phase:

Previously we met once a month, now that we do not have a project, the process became slow, this is how it goes when we do not have funding, however, still we are meeting once in three- or four-months' time. (Local community representative) [Interviewee quote 8].

Interviewees identified the absence of financial support and relevant project activities as being responsible for the slower progress in TLCC and WLCC activities. However, they also pointed toward key local actors' (e.g., the mayor) contributions, in particular in facilitating TLCC meetings, being open to innovative ideas, and developing strong communication and networking skills. These local leaders showed a promising and positive attitude in their efforts and contributed to Pourashavas' activities to maintain good water quality and drainage improvements in the Mymensingh city area. For example, most of the interviewees (85\% of respondents) praised the city mayor for his interest and dedication to TLCC activities and stated that although the TLCC is a project-based activity, the mayor is using this platform for important decision-making and as a means for seeking regime guidance from sector experts on solutions.

Nevertheless, community leaders who were interviewed (20\% of the interviewees) consider themselves removed from the formal decision-making processes that influence Pourashava activities and suggest that this is due to their political stance (they belong to the opposition party, not the current ruling party). Local community leaders raised their frustration regarding the formal decision-making processes as "project dependent and short term, and let us see how long it is going to survive" (Interviewee quote 9). A few interviewees pointed to this critical context of leadership capability and urged training for grassroots leaders to enhance sustainable water management.

The activities by the actor clusters (TLCC/WLCC) in the hybrid and polycentric governance structure in Mymensingh are providing opportunities for multi-level interactions, community participation and bridging activities for policy implementation. While these are identified as contributing to local governance capacity, challenges remain at other administrative levels, such as the regional and national levels. These actors are still dominated by a top-down approach that lacks bridging capacities and coordination between central agencies. Such problems have persisted for a long time in Bangladesh and in many other developing countries (Cinner et al., 2012; Satumanatpan et al., 2014; Nguyen et al., 2017).

In this context and as an alternative to the top-down approach, the MDSP initiates bottom-up strategies in city planning and its lead organization acts as a bridging organization. This niche project is designed to bridge national and local-scale state agencies. The MSDP staff interviewed stated that they are very excited about their project, which is producing a manual to guide different agency activities at the local scale:

The MSDP project is a first of its kind as a collaborative project between two national-scale state agencies to understand how to integrate and translate planning into practice. (MSDP team member) [Interviewee quote 10].

As Table 3 shows, the MSDP involved state and non-state actors, including those already engaged with the UGIIP project, as well as new relevant actors. MSDP activities involved focus group discussions with relevant professionals and experts with the aim of sharing knowledge and opinions related to future city planning, including collectively agreeing upon problem identification and discussions related to possible solutions. MSDP is described by an interviewee as "a unique approach due to its emphasis on community involvement as part of 
facilitating a bottom-up strategy" [Interviewee quote 11]. Over the duration of the project, the MSDP team undertook fortytwo distinct field visits, held several workshops, seminars and group discussions. The reason for such diverse consultation is to make the community familiar with the project's targets and the relevance to Mymensingh city's ongoing development.

While sharing field experiences during research interviews, members of the MSDP planning team acknowledged the enthusiastic participation and support of the relevant nonstate actors (i.e., TLCC/WLCC/community-based organization) but also vented their frustration with what they perceived as inadequate participation and collaboration by other state actors, such as government agencies. The challenges confronting state agency involvement was identified by interviewees as: (i) lack of coordination across state agencies; (ii) bureaucratic delays and complex decision-making processes at national level; and (iii) distrust across state agencies (evidenced in interviewee quotes). After finalizing the plan, the MSDP team developed a model to showcase their planned output and this received wider acceptance from the citizens. Although this project is still awaiting formal government approval, the Pourashava authority has already started to use this document as their vision and guidance for future urban water management developments.

Table 4 summarizes the understanding of the critical enablers and emerging adaptive attributes identified in this research using the ACA framework and focussing on sustainable urban water management. The next section will further elaborate on how these enablers are providing a useful platform for developing capacity to deliver adaptive attributes and guide sustainable transformation pathways for urban water governance in Mymensingh.

\section{Capacity Development and Pathways}

Three major governance reforms, since the inception of the Mymensingh urban water system in 1893 to the study in 2017, were identified utilizing the multi-level perspective (MLP) as an organizing framework to differentiate between niche and regime projects or activities (Table 2). These governance reforms unfolded against a background of three corresponding sociopolitical contexts in Bangladesh and contributed to shifting and shaping the urban water management in Mymensingh. The governance approaches in each of the three developmental periods have distinct characteristics and interlinkages across institutions and actors (see Table 2) and began differently than the dynamics in Bangladesh more broadly and in Dhaka in particular. Although Mymensingh has a different "starting line" to Dhaka, its urban water development was similar to broader Bangladesh's regime-driven urban water development until the recent implementation of the niche projects (e.g., UGIIP and MSDP).

The first developmental period (1893-1995) in Mymensingh saw major institutional setups where key actors (i.e., Pourashava, DPHE, and LGED) were facing tremendous challenges in the delivery of water and sanitation services. These challenges stemmed from: (1) different institutional ideologies and a lack of coordination between the central agencies; (2) the Pourashava not being involved in the capacity development initiatives, and
(3) transnational actors (e.g., ADB) having a dominant influence without adequate knowledge of the implementation context.

In the second developmental period (1996-2010), Mymensingh experienced a major reform in the institutional and actor space, where for the first time in the history of Bangladesh, Pourashavas were involved in the decision-making processes and started to enjoy some level of financial autonomy. In the institutional space, this period saw the formulation and implementation of relevant policies, legislation and plans (see Table 2), which were key to involving Pourashavas as the major implementation authority and engaging them in the capacity development initiatives. Further, this evolution in the institutional space also supported other developments, such as social movements concerned with environmental conservation and water security, river-water pollution and wetland conservation for urban water drainage. Together these changes in institutional and actor space created a platform where innovative projects such as UGIIP and other urban water and sanitation related projects started to shape Mymensingh's urban water system.

The contemporary development of the urban water system in Mymensingh (2011-2017 and still evolving) is distinct and shows several niche innovations that may guide future developmental pathways. The ACA framework identified institutional rearrangement and formation of new actor clusters (see Figure 4) through niche projects, which are shaping Pourashava's governance system into a more hybrid form. These niche projects are also supporting the development of polycentric characteristics, in which decision-making and financial autonomy have been directed toward local actor clusters, involving state and non-state actors. This hybrid governance approach is reflected in the academic literature as having the potential to advance SUWM implementation (Pahl-Wostl, 2007; Brown et al., 2009; Clark and Semmahasak, 2013; Kuzdas et al., 2015).

The emerging hybrid and polycentric governance structure in Mymensingh is acting as the key enabler to support sustainable change and is creating platforms to facilitate the complex interactions among engaged actors (both the state and nonstate) necessary to develop connections and linkages and form new networks. These complex interactions and diverse actors' engagements and new networks are important enabling factors for facilitating collective effort, integrating local knowledge and raising awareness and are critical for operationalisation of adaptive governance principles and thus can support advancing SUWM (Table 4).

Although quantitative analysis of the networks' centrality and cohesion is beyond the research scope, the network formation and increased informal engagements identified in this study appear to be facilitating active participation and collaboration and warrant further investigation in follow-up work. The solid-waste disposal and production of manure as an output through coordinated activities driven by the NGOs and research institute is an example of innovation and informal activity in Mymensingh. Such activities have also proven important for cross-scale learning, development of a shared vision and building self-organizing capacity (Larson et al., 2013; Butler et al., 2014; 


\section{Mymensingh urban water governance}

\section{Enabling context}

\section{Hybrid Governance with \\ - Actors clusters at multiple levels of implementation (e.g., TLCC/WLCC) [A, B, C, E]} polycentric characteristic

Participatory decision-making processes for city development activities (e.g., 20-years of master plan for city development includes participatory planning approach and integration of disaster-risk-reduction strategies, Interviewee quote 6

Decision-making and financial autonomy directed toward local authority, which includes wider community involvement (e.g., developing the capacity of the non-state actors to raise their voices over their preferences, which indicates some level of flexibility in decision-making processes despite strong centralized control, Interviewee quote 7)

State and non-state actors' participation in policy translation (e.g., TLCC/WLCCs from UGIIP project, Interviewee quote 5) [B, C, D, E, F, H, G]

- Increasing levels of trust observed upon state actors and local leaders (e.g., displaying Pourashava vision and producing yearly citizen charter, Interviewee quote 2) $[\mathbf{H}, \mathbf{I}, \mathbf{N}]$

Bridging organization, network formation and leadership

Displaying Pourashava vision and citizen charter at Pourashava premises indicating developing shared understanding and motivation for change [Interviewee quote 12] [H, I]
Different layers of decision-making committees displays overlapping memberships, which encourages a base of diverse knowledge and sharing (e.g., Figure 1)

Increasing scope for knowledge generation and mobilization observed which further increased opportunities for information sharing (e.g.,

TLCC/WLCC/Yard meetings, 20-years master plan, Figure 1)

Diverse actors clusters are offering a platform to capture community preferences into state driven activities and linking diverse knowledge base into policy implementation (interviewee quote 6 and 7 ) [D, J, K]

- Formal activities and informal activities traced in support to delivering water and sanitation services to the citizen, where informal engagement found more broad and effective than the formal system (formal activities such as, augmentation of piped network, water connection in informal settlements, and informal activities, such as, NGOs driven initiatives for solid waste collection for reducing blockage of drains, several initiatives by the social activist for reducing river water pollution, handwashing programme in schools) [K]

- Some examples of collaborative efforts across state and non-state actors evidenced as played a crucial role in bringing innovative ideas and approach to support sustainable urban water-related practices with occasional coordination (e.g., TLCC driven collective action for solid waste disposal system and manure production) [L]

- Capacity development initiatives started to target state and non-state actors (e.g., UGIIP, MSDP) [D, J, M]

Although strongly centralized approach still exist with little scope for local institutions, increasing awareness and capacity started to influence policy implementation and accessing resources (Interviewee quote 6 and 7) [E,F, N]

- TLCC/WLCC/MSDP emerging as a bridging organization and reducing gaps between community and local implementing authority (Interviewee quote $6,7,10$ and 11)

Some leaders are observed as championing change at a different level of implementation and further creating opportunities for local leaders to support sustainable initiatives (Interviewee quote 3 and 5) [M,N,O]
A. Layered/multi-level

B. Participatory approach and in the processes of new network formation

C. A combination of topdown and bottom-up approach.

D. Diverse actors base

E. Power transfer

F. Flexibility decision-making

G. Integrated approach in city development

H. Trust and fairness

I. Shared goals and vision

J. Diverse

interconnected knowledge base

K. Formal and informa activities

L. Coordination collaboration

M. Linking

N. Bridging gaps

o. Championing 
Orchard et al., 2015). A number of other examples mentioned by the interviewees indicate an increasing level of policy translation by the local and international NGOs which is actively contributing to awareness raising and capacity development including in slums and rural areas.

Fairness in resource access and distribution, accountability of state actors, and increasing trust between state and non-state actors are identified in the ACA framework as important adaptive attributes for developing capacity to advance sustainable resource governance. In the case of Mymensingh Pourashava, their initiatives and the newly developed polycentric actor clusters (TLCC/WLCC/community-based organization) are creating pressure on the implementation authority to ensure accountability and fair access to resources (e.g., the need to display report cards in Pourashava premises) (Table 4). This indicates a restoration of some level of trust to the state actors and a redefining of the boundaries of authorization and power over resource access and management.

Nevertheless, the hybrid governance structure in Mymensingh is project dependent (UGIIP, MSPD) and requires financial investment and strategic guidance from the transnational actors (e.g., the ADB, UNDP who act as donors, and investors). Sustainable transition and adaptive governance scholars have found the impact of transnational actors to be important for local capacity formation (Nastar, 2014; Panditharatne, 2016), dealing with informal institutions and with weak formal institutions (Rouillard et al., 2014; Orchard et al., 2015; Bahauddin et al., 2016) and to support leapfrogging theories (see Watson and Sauter, 2011; Poustie et al., 2015). However, the present research did not explicitly identify the contribution of transnational actors, but rather critically examined the projects that were designed and implemented in Mymensingh with their support. The research found that these donor-dependent niche projects and associated actor clusters are creating a promising platform to deliver adaptive attributes, such as those framed by the ACA, to increase the level of local capacity (see Table 4). Although donor support was absent for a while (between donor-funded projects), a few TLCC and WLCC meetings were organized and facilitated by key local leaders of Mymensingh city and the councils were involved in the Pourashava's activities with other projects, such as the MSDP (a niche project).

The UGIIP actor clusters created different platforms (TLCC/WLCC/Yard meetings), which acted as a quasi-formal site for knowledge generation, sharing and integration, while the MSDP platform facilitated and supported the integration of local and scientific knowledge to define local-scale problems and solutions. In turn, these collective platforms helped to reshape people's perception of urban water development and the services they offer. For example, developing a Pourashava Master Plan through the MSDP project, using a demand-driven approach, is itself an example of "learning-by-doing" (MSDP completion report, 2016). In interviews, the MSDP team members reflected upon their learning experiences; for example, "fascinating and definitely learned innovative ways of urban planning" (MSDP staff member) [Interviewee quote 12]. Over the course of the project, there were a number of interactive workshops and group discussions where citizens discussed their problems, recommended possible solutions and finally prepared a priority list for implementation. Key challenges facing the community were identified as vulnerability to earthquake hazards, urban flooding due to drainage congestion and groundwater depletion. Based on the community's input the emphasis of this master plan was to identify potential sites for reservoirs and to design future infrastructure that can withstand earthquakes.

The changes observed in governance approaches and actor interactions (Tables 2, 4) using the understanding developed through the MLP and the ACA framework indicate increasing adaptive capacity in Mymensingh Pourashava. However, the issue of effective functioning and advancing sustainable delivery of urban water-related services depends also on institutional rearrangements or functioning at other policy levels. For example, DPHE and LGED both are crucial for Mymensingh Pourshava and therefore how these two agencies are functioning and collaborating with each other is important. While there has been increased coordination and collaboration observed at the local scale, there remain gaps at the agency level where they face challenges in effective coordination with each other, in order to address the unique problems faced in Mymensingh city.

However, DPHE and LGED (the two most central actors in the organizational domain, see Figures 3, 4, responsible for providing support for water resource management for Pourashavas) have little coordination with one another. Although "lack of coordination" and "fragmented institutions" are identified as a persistent problem for sustainable water management (Falk et al., 2009; Cinner et al., 2012; Pahl-Wostl et al., 2012; Butler et al., 2014; Grady et al., 2016; Azhoni et al., 2017), this provides an opportunity in Mymensingh for an integrated approach to governance "that offers an appropriate mix of local and regional institutions, with strong support for strengthening of these local institutions by national authorities" (Chan et al., 2016, p. 13). This increasing communication and poly-centric approach was apparent in the way the structure of water governance changed across lower implementation levels and significantly influenced the city's water supply and sanitation system. For example, MSDP's innovative approach for planning small-scale decentralized water supply systems in slum communities is an example of adopting a suitable alternative to that context instead of going to the conventional centralized solution.

It appears that these niche projects have not only generated learning opportunities which previously identified as an ongoing challenge but also supported activities that enable the community to influence state decisions. However, there remains the challenge of effective integration of community preferences into policy implementation since Bangladesh is dominated by a rigid centralized approach. According to interview participants, although the Pourashava is now ahead in their city development planning (e.g., drainage networks, wetland management) it now involves not only NGOs and citizens but also experts and professionals in formulating their plans. However, a persistent challenge appears to be the absence of guidelines on how to execute these plans. This indicates a need for continued donor involvement and guiding to address future challenges and developing capacities. "Mymensingh Pourashava now has 
wonderful planning; but I am not convinced that they have the necessary capacity to execute these plans." (NGO worker) [Interviewee quote 13].

\section{CONCLUSION}

This article has presented an analysis of Mymensingh, a secondary city in Bangladesh which itself is a developing country with ambitions to become middle-income, focusing on its water sector development, where new institutional arrangements and relevant actor clusters are shaping the progress of the urban water service delivery system. The article showed that Mymensingh city is experiencing a shift toward hybrid and polycentric governance, new network development, shared experiences and emergent learning processes which together contribute to improved policy formulation (and implementation). However, there remains a lack of critical knowledge and guidance to further its adaptive capacities, and to move from planning to implementation.

In addition to being evolutionary and "new-in-context" for secondary city development, the UGIIP (funded by the Asian Development Bank to improve the functionality of the urban utility service provider by developing local infrastructure and improving local governance capacity) and MSDP [UN funded long-term project to improving community resilience through increasing formal and informal participation and collaboration within and between government agencies, with non-government organizations (NGOs), and broader civil society] initiatives are considered examples of innovation and promising pathways to support a shift toward a new governance model. This new model exhibits hybrid and polycentric institutional arrangements, which, along with other critical adaptive attributes presented in Table 4, are important for leading sustainable water resource management in a developing-country context. Prior to the UGIP and MSDP projects, the Pourashava's citizens were mostly responsible for their own water supply and sanitation. While the overall situation of water management has not yet improved and was still in a primitive stage during the research period, a significant change in people's attitudes (citizens and state actors) was observed. Citizens, including those in slum communities, are more aware of their physical and ecological health, and are engaging with their community bodies (e.g., the slum organizations, NGOs etc.) to have their voices heard.

This change in the actors' dynamics reflects a redefinition of the ongoing hydro-social contract between government and citizens, in which the government is shifting away from its traditional role of being solely responsible for water-related services, and non-state actor's participation is increasing and starting to influence state water-related activities. Citizens of Mymensingh have recognized their power and capacity to influence state activities and have growing confidence in their ability to organize, and to identify and respond to the (water provisioning) problem themselves. This is new to the context of Bangladesh and reveals a new start line for Mymensingh, that is different from the larger city of Dhaka where change is slow, as identified by Yasmin et al. (2018). Although this indicates an increasing complexity in actor interactions, this is offset by their improved adaptive capacity and governance approaches. The opportunities for employing a new governance structure (hybrid and polycentric) identified through this research suggest that recognizing and guiding such complexity is essential to facilitate sustainable growth.

The findings presented in this article highlight a shift in governance capacity that is significantly influencing power dynamics and decision-making processes for managing the urban water system in Mymensingh. A focus on the enablers for delivering adaptive attributes and capacity has highlighted the evolving management and governance structure and transition context in Mymensingh Pourashava. The analysis found an emergence of new institutional and actor engagements, which are building leadership and bridging capacity to improve linkages and integration of knowledge. These adaptive governance approaches need nurturing (at local scale) if they are to become mainstream practices. However, these approaches are also strongly dependent on donor investment and guidance, while the involvement of state agencies remains insignificant. The potential absence of ongoing donor support will likely determine the impact of these activities in the future, unless strong local champions (e.g., Mayor, TLCC members) declare their intention to take over responsibility for maintaining them. This article has outlined the adaptive governance principles that are capable of guiding sustainable transformation. A lack of guidance on how to mainstream such practices would be a barrier to sustainability in this emerging city.

\section{DATA AVAILABILITY STATEMENT}

The raw data supporting the conclusions of this article will be made available by the authors, without undue reservation.

\section{ETHICS STATEMENT}

The studies involving human participants were reviewed and approved by Monash University Ethic Committee, Clayton, Melbourne, Australia. The patients/participants provided their written informed consent to participate in this study.

\section{AUTHOR CONTRIBUTIONS}

TY is responsible for conceive, design, collection and analysis of data including first drafting of the manuscript. All authors are responsible for writing, revising, finalizing and approving the submitted version.

\section{ACKNOWLEDGMENTS}

This study was supported from the Monash University and the University of Birmingham Institute for Global Innovation via the Environmental Pollution Solutions emerging theme, led by Professor Iseult Lynch, is gratefully acknowledged (IGI ID 4054). 


\section{REFERENCES}

ADB (2015). Asian Development Bank. Strengthening Municipal Governance Through Performance-Based BuBiswasdget Allocation in Bangladesh Publication Stock No. ARM157795-2. Available online at: https://www.adb.org/sites/ default/files/publication/177452/strengthening-municipal-governancebangladesh.pdf

ADB. (2009). Urban Sector and Water Supply and Sanitation in Bangladesh: An Exploratory Evaluation of the Programs of $A D B$ and Other Aid Agencies. Publication Reference Number: SAP: BAN 2009-02, Sector Assistance Program Evaluation. Available online at: https://www.oecd.org/countries/bangladesh/ 47148619.pdf

Agyenim, J. B., and Gupta, J. (2012). IWRM and developing countries: implementation challenges in Ghana. Phys. Chem. Earth Parts 47, 46-57. doi: 10.1016/j.pce.2011.06.007

Ahammad, R., Hossain, M. K., and Husnain, P. (2014). Governance of forest conservation and cobenefits for Bangladesh under changing climate. J. For. Res. 25, 29-36. doi: 10.1007/s11676-014-0430-9

Azhoni, A., Holman, I., and Jude, S. (2017). Contextual and interdependent causes of climate change adaptation barriers: insights from water management institutions in Himachal Pradesh, India. Sci. Total Environ. 576, 817-828. doi: 10.1016/j.scitotenv.2016.10.151

Bahauddin, K. M., Rahman, N., and Hasnine, M. T. (2016). Environmental reviews and case studies: public perception, knowledge, and participation in climate change adaptation governance in the Coastal Region of Bangladesh using the social ecological inventory (SEI) tool. Environ. Pract. 18, 32-43. doi: $10.1017 /$ S1466046615000393

Bangladesh Local Government Acts and Rules (2015). Local Government and Rural Development MInistry. Government of Bangladesh.

Berkhout, F., Verbong, G., Wieczorek, A. J., Raven, R., Lebel, L., and Bai, X. (2010). Sustainability experiments in Asia: innovations shaping alternative development pathways? Environ. Sci. Policy 13, 261-271.

Biggs, E. M., Duncan, J. M., Atkinson, P. M., and Dash, J. (2013). Plenty of water, not enough strategy: how inadequate accessibility, poor governance and a volatile government can tip the balance against ensuring water security: the case of Nepal. Environ. Sci. Policy 33, 388-394. doi: 10.1016/j.envsci.2013.07.004

Biswas, A.K., and Tortajada, C. (2010). Future water governance: problems and perspectives. Int. J. Water Resourc. Dev. 26, 129-139. doi: 10.1080/07900627.2010.488853

Brown, R. R., Keath, N., and Wong, T. H. (2009). Urban water management in cities: historical, current and future regimes. Water Sci. Technol. 59, 847-855. doi: 10.2166/wst.2009.029

Bryman, A. (2004). Qualitative research on leadership: a critical but appreciative review. Leadersh. Q. 15, 729-769. doi: 10.1016/j.leaqua.2004.09.007

Bunnell, T., and Maringanti, A. (2010). Practising urban and regional research beyond metrocentricity. Int. J. Urban Reg. Res. 34, 415-420. doi: 10.1111/j.1468-2427.2010.00988.x

Butler, J. R. A., Suadnya, W., Puspadi, K., Sutaryono, Y., Wise, R. M., Skewes, T. D., et al. (2014). Framing the application of adaptation pathways for rural livelihoods and global change in eastern Indonesian islands. Glob. Environ. Change 28, 368-382. doi: 10.1016/j.gloenvcha.2013. 12.004

Chan, N., Roy, R., and Chaffin, B. (2016). Water governance in Bangladesh: an evaluation of institutional and political context. Water 8, 403. doi: $10.3390 /$ w8090403

Cinner, J. E., Daw, T. M., McClanahan, T. R., Muthiga, N., Abunge, C., Hamed, S., et al. (2012). Transitions toward co-management: the process of marine resource management devolution in three east African countries. Glob. Environ. Change 22, 651-658. doi: 10.1016/j.gloenvcha.2012. 03.002

Clark, J. R., and Semmahasak, C. (2013). Evaluating adaptive governance approaches to sustainable water management in north-west Thailand. Environ. Manage. 51, 882-896. doi: 10.1007/s00267-012-9993-4

Creswell, J. W. (2013). Research design: Qualitative, Quantitative, and Mixed Methods Approaches. California: Sage Publications.

de Noronha, T., and Vaz, E. (2015). Framing urban habitats: the small and medium towns in the peripheries. Habitat Int. 45, 147-155. doi: 10.1016/j.habitatint.2014.06.025
Dietz, T., Ostrom, E., and Stern, P. C. (2003). The struggle to govern the commons. Science 302, 1907-1912. doi: 10.1126/science.1091015

Falk, T., Bock, B., and Kirk, M. (2009). Polycentrism and poverty: experiences of rural water supply reform in Namibia. Water Alternat. 2, 115. Available online at: https://www.water-alternatives.org/index.php/all-abs/39-a2-1-8/file

Folke, C., Hahn, T., Olsson, P., and Norberg, J. (2005). Adaptive governance of social-ecological systems. Annu. Rev. Env. Resour. 30, 441-473. doi: 10.1146/annurev.energy.30.050504.144511

Grady, A., Gersonius, B., and Makarigakis, A. (2016). Taking stock of decentralized disaster risk reduction in Indonesia. Nat. Haz. Earth Syst. Sci. 16, 2145-2157. doi: 10.5194/nhess-16-2145-2016

Gupta, D. (2012). Beyond the metropolis. Seminar 629, 73-76.

Halbe, J., Pahl-Wostl, C., Sendzimir, J., and Adamowski, J. (2013). Towards adaptive and integrated management paradigms to meet the challenges of water governance. Water Sci. Technol. 67, 2651-2660. doi: 10.2166/wst.2013.146

Huntjens, P., Lebel, L., Pahl-Wostl, C., Camkin, J., Schulze, R., and Kranz, N. (2012). Institutional design propositions for the governance of adaptation to climate change in the water sector. Glob. Environ. Change 22, 67-81.

IBRD, I. (1972). Land and Water Resource Sector Study Bangladesh (No. 8). Technical Report.

Jaglin, S., and Bousquet, A. (2011). "Conflicts of influence and competing models: the boom in community-based privatization of water services in sub-Saharan Africa," in Urban Water Conflicts, Vol. 169 (London: Routledge in association with GSE Research), 169-193.

Kooiman, J., and Jentoft, S. (2009). Meta-governance: values, norms and principles, and the making of hard choices. Public Adm. 87, 818-836. doi: 10.1111/j.1467-9299.2009.01780.x

Koop, S. H., and van Leeuwen, C. J. (2015). Assessment of the sustainability of water resources management: a critical review of the city blueprint approach. Water Resourc. Manag. 29, 5649-5670. doi: 10.1007/s11269-015-1139-z

Kuzdas, C., Wiek, A., Warner, B., Vignola, R., and Morataya, R. (2015). Integrated and participatory analysis of water governance regimes: the case of the costa rican dry tropics. World Dev. 66, 254-268. doi: 10.1016/j.worlddev.2014.08.018

Larson, S., Alexander, K. S., Djalante, R., and Kirono, D. G. (2013). The added value of understanding informal social networks in an adaptive capacity assessment: Explorations of an urban water management system in Indonesia. Water Resourc. Manag. 27, 4425-4441. doi: 10.1007/s11269-013$0412-2$

Makropoulos, C. K., and Butler, D. (2010). Distributed water infrastructure for sustainable communities. Water Resourc. Manag. 24, 2795-2816. doi: $10.1007 / \mathrm{s} 11269-010-9580-5$

Meuleman, L. (2008). Public Management and the Metagovernance of Hierarchies, Networks and Markets: The Feasibility of Designing and Managing Governance Style Combinations. The Hague: Springer Science \& Business Media.

MSDP (2015). Mymensingh Strategic Development Plan (2011-2031). Available online at: http://udd.portal.gov.bd/sites/default/files/files/udd.portal. gov.bd/publications/c02c0a00_4471_4763_8659_7e04028b0cb5/MSDP \%20Monograph.pdf.

Nastar, M. (2014). What drives the urban water regime? An analysis of water governance arrangements in Hyderabad, India. Ecol. Soc. 19, 57. doi: 10.5751/ES-06570-190257

National Water Policy (NWP) (1999). Ministry of Water Resources Government of the People's Republic of Bangladesh. Available online at: http://nda.erd.gov.bd/ files/1/Publications/Sectoral\%20Policies\%20and\%20Plans/National\%20Water \%20Policy\%201999.pdf

Newig, J., and Koontz, T. M. (2014). Multi-level governance, policy implementation and participation: the EU's mandated participatory planning approach to implementing environmental policy. $J$. Euro. Public Policy 21, 248-267. doi: 10.1080/13501763.2013.8 34070

Nguyen, Q. A., Miller, F., Bowen, K., and Tan Sinh, B. (2017). Evaluating capacity for climate change adaptation in the health and water sectors in Vietnam: constraints and opportunities. Clim. Dev. 9, 258-273. doi: $10.1080 / 17565529.2016 .1146118$

OECD (2011). Water Governance in OECD Countries: A Multi-level Approach. Paris: OECD.

OECD (2015). OECD Principles on Water Governance, Note by the SecretaryGeneral, Doc C (2015) 71 Ref: JT03376062). Paris: OECD Publishing. Available 
online at: https://www.oecd.org/cfe/regional-policy/OECD-Principles- onWater-Governance.pdf

Orchard, S. E., Stringer, L. C., and Quinn, C. H. (2015). Impacts of aquaculture on social networks in the mangrove systems of northern Vietnam. Ocean Coast. Manag. 114, 1-10. doi: 10.1016/j.ocecoaman.2015.05.019

Owusu, G. (2005). Small towns in Ghana: justifications for their promotion under Ghana's decentralisation programme. Afr. Stud. Q. 8, 48-69.

Pahl-Wostl, C. (2007). Transitions towards adaptive management of water facing climate and global change. Water Resour. Manag. 21, 49-62. doi: 10.1007/s11269-006-9040-4

Pahl-Wostl, C. (2009). A conceptual framework for analysing adaptive capacity and multi-level learning processes in resource governance regimes. Glob. Environ. Change 19, 354-365. doi: 10.1016/j.gloenvcha.2009.06.001

Pahl-Wostl, C., Lebel, L., Knieper, C., and Nikitina, E. (2012). From applying panaceas to mastering complexity: toward adaptive water governance in river basins. Environ. Sci. Policy 23, 24-34. doi: 10.1016/j.envsci.2012.07.014

Panditharatne, C. (2016). Institutional barriers in adapting to climate change: a case study in Sri Lanka. Ocean Coast. Manag. 130, 73-78. doi: 10.1016/j.ocecoaman.2016.06.003

Pierre, J., and Peters, B.G. (2000). Governance, Politics and the State. Basingstoke: Macmillan

Poustie, M. S., Deletic, A., Brown, R. R., Wong, T., de Haan, F. J., and Skinner, R. (2015). Sustainable urban water futures in developing countries: the centralised, decentralised or hybrid dilemma. Urban Water J. 12, 543-558. doi: 10.1080/1573062X.2014.916725

Regmi, B. R., Star, C., and Leal Filho, W. (2016). Effectiveness of the local adaptation plan of action to support climate change adaptation in Nepal. Mitig. Adapt. Strateg. Glob. Chang. 21, 461-478.

Rijke, J., Farrelly, M., Brown, R., and Zevenbergen, C. (2013). Configuring transformative governance to enhance resilient urban water systems. Environ. Sci. Policy 25, 62-72.

Rip, A., and Kemp, R. (1998). "Technological change," in Human Choice and Climate Change, eds S. Rayner and E.L. Malone (Columbus, OH: Battelle Press), 327-399.

Rondinelli, D. A., Nellis, J. R., and Cheema, G. S. (1983). Decentralization in Developing Countries. World Bank Staff Working Paper 581. 13-28.

Rotmans, J., Kemp, R., and Van Asselt, M. (2001). More evolution than revolution: transition management in public policy. Foresight 3, 15-31. doi: $10.1108 / 14636680110803003$

Rouillard, J. J., Benson, D., and Gain, A. K. (2014). Evaluating IWRM implementation success: are water policies in Bangladesh enhancing adaptive capacity to climate change impacts? Int. J. Water Resourc. Dev. 30, 515-527. doi: 10.1080/07900627.2014.910756

Satumanatpan, S., Senawongse, P., Thansuporn, W., and Kirkman, H. (2014). Enhancing management effectiveness of environmental protected areas, Thailand. Ocean Coast. Manag. 89, 1-10. doi: 10.1016/j.ocecoaman.2013.12.001

Shah, M. (2013). Water: towards a paradigm shift in the Twelfth plan. Econ. Poli. Wkly. 48, 41-52. Available online at: https://citeseerx.ist.psu.edu/viewdoc/ download?doi=10.1.1.1068.7316

Sowman, M., and Raemaekers, S. (2018). Socio-ecological vulnerability assessment in coastal communities in the BCLME region. J. Mar. Syst. 188, 160-171. doi: 10.1016/j.jmarsys.2018.01.008
Turton, A. R., and Ohlsson, L. (1999). Water scarcity and social adaptive capacity: towards an understanding of the social dynamics of managing water scarcity in developing countries. MEWREW Occas. Paper 9, $15-17$.

Tutusaus, M., Schwartz, K., and Smit, S. (2018). The ambiguity of innovation drivers: The adoption of information and communication technologies by public water utilities. J. Clean. Prod. 171, S79-S85. doi: 10.1016/j.jclepro.2016.08.002

UN-Habitat (2006). State of the World's Cities 2006/7. New York, NY: UN-Habitat.

United, Nations, Department of Economic and Social Affairs, Population Division (2015). World Urbanization Prospects: The 2014 Revision, (ST/ESA/SER.A/366). Available online at: https://population.un.org/wup/Publications/Files/ WUP2014-Report.pdf

Van de Meene, S. J., Brown, R. R., and Farrelly, M. A. (2011). Towards understanding governance for sustainable urban water management. Glob. Environ. Change 21, 1117-1127. doi: 10.1016/j.gloenvcha.2011.04.003

Watson, J., and Sauter, R. (2011). Sustainable innovation through leapfrogging: a review of the evidence. Int. J. Technol. Glob. 5, 170-189. doi: 10.1504/IJTG.2011.039763

Wong, T. H., and Brown, R. R. (2009). The water sensitive city: principles for practice. Water Sci. Technol. 60, 673-682. doi: 10.2166/wst.2009.436

World Bank. (2017). Annual Report 2017. World Bank. Available online at: http:// pubdocs.worldbank.org/en/908481507403754670/Annual-Report-2017WBG.pdf

Yasmin, T., Farrelly, M., and Rogers, B. C. (2019). Adaptive governance: a catalyst for advancing sustainable urban transformation in the global South. Int. J. Water Resourc. Dev. 36, 818-831: doi: 10.1080/07900627.2019.1611548

Yasmin, T., Farrelly, M. A., and Rogers, B. C. (2018). Evolution of water governance in Bangladesh: an urban perspective. World Dev. 109, 386-400. doi: 10.1016/j.worlddev.2018.05.003

Zermoglio, F., Khan, A., Dahodwala, S., and Perine, C. (2020). Climate Vulnerability Assessment Impacts on Health Outcomes in Secondary Cities of Bangladesh. United States Agency for International Development (USAID), Cambridge University Press.

Conflict of Interest: The authors declare that the research was conducted in the absence of any commercial or financial relationships that could be construed as a potential conflict of interest.

Publisher's Note: All claims expressed in this article are solely those of the authors and do not necessarily represent those of their affiliated organizations, or those of the publisher, the editors and the reviewers. Any product that may be evaluated in this article, or claim that may be made by its manufacturer, is not guaranteed or endorsed by the publisher.

Copyright $(2022$ Yasmin, Farrelly, Rogers, Krause and Lynch. This is an open-access article distributed under the terms of the Creative Commons Attribution License (CC $B Y)$. The use, distribution or reproduction in other forums is permitted, provided the original author(s) and the copyright owner(s) are credited and that the original publication in this journal is cited, in accordance with accepted academic practice. No use, distribution or reproduction is permitted which does not comply with these terms. 